\title{
Adsorption of mercury ions from synthetic and real wastewater aqueous solution by functionalized multi-walled carbon nanotube with both amino and thiolated groups
}

\author{
Mojtaba Hadavifar ${ }^{\mathrm{a}}$, Nader Bahramifar ${ }^{\mathrm{b} *}$, Habibollah Younesi ${ }^{\mathrm{a}}, \mathrm{Qin} \mathrm{Li}^{\mathrm{c}}$ \\ a Department of Environmental Science, Faculty of Natural Resources, Tarbiat Modares \\ University, P.O. Box 46414-356, Noor, Iran \\ ${ }^{\mathrm{b}}$ Department of chemistry, Payam Noor University (PNU), POBOX 1939-3697, Tehran, Iran \\ ${ }^{c}$ Department of Environmental Engineering \& Queensland Micro- and Nanotechnology Centre, \\ Griffith University, Nathan Campus, P.O. Box 4111, Brisbane, Australia
}

\section{Abstract}

The functionalization of multi-walled carbon nanotubes (MWCNTs) was using with ethylenediamine and cyanuric chloride and sodium 2-mercaptoethanol as efficient ways to introduce amine and thiol functional groups onto the nanotube sidewalls. The synthesized amino and thiolated MWCNTs were characterized by Fourier transform infrared spectroscopy (FT-IR), thermogravimetric analysis (TGA), X-ray photoelectron spectroscopy (XPS) and scanning electron microscope (SEM). A series of batch adsorption experiments were conducted to study the effect of $\mathrm{pH}$, dose, metal concentration and temperature on $\mathrm{Hg}(\mathrm{II})$ uptake by the functionalized, MWCNTs. The isotherm data were analyzed for possible agreement with the Langmuir than Freundlich models, while the equilibrium data were fitted better by Langmuir model. The pseudo-first-order and pseudo-second-order rate equations were tested on kinetic

\footnotetext{
* Corresponding author: Tel: +98 151325896, Fax: +98 1513258960, E-mail address: nbahramifar@yahoo.com (N. Bahramifar)
} 
data and an adsorption followed the pseudo-second-order rate kinetics. Based on the thermodynamic data of $\Delta \mathrm{H}^{\mathrm{o}}, \Delta \mathrm{S}^{\mathrm{o}}$ and $\Delta \mathrm{G}^{\mathrm{o}}$ obtained, it can be concluded that the $\mathrm{Hg}(\mathrm{II})$ ion adsorption on the functionalized MWCNTs is exothermic, spontaneous and the mechanism of physical adsorption. In a fixed-bed column adsorption, the effects of bed height, flow rate and initial ion concentration on the breakthrough curve were investigated, on which the predictions were found to be satisfactory both by the Yan and Thomas models. Lastly, we found out the assynthesized MWCNTs with good efficiency for $\mathrm{Hg}($ II) removal from real wastewater.

Keywords: Functionalized MWCNTs, mercury adsorption, thiol functional group, thermodynamic parameters, kinetics

\section{Introduction}

Mercury is a highly toxic and accumulative metal and its compounds, especially methyl mercury, are neurotoxins which cause blockage of the enzyme sites and interfere in protein synthesis. The fate of inorganic, mercury ions in nature is its turning into methyl mercury due to the aerobic action of microorganisms [1]. The main sources of mercury ions in aquatic ecosystems are divergent, chloralkali wastewater, oil refineries, power generation plants, paper and pulp manufacturing, rubber processing and fertilizers industries [2]. Various methods have been used for removing heavy metals from aqueous environment such as reverse osmosis, chemical precipitation, ion exchange, coagulation and adsorption [3]. Many carbon-based nanoparticles (CNTs) have been developed to remove heavy metals from aqueous media [2,4-6]. They are promising material for numerous applications due to their unique electrical, mechanical, thermal, optical and chemical properties. In addition, CNTs are proven to be superior adsorbents for 
several divalent metal ions in water, because of their capability to establish $(\pi-\pi)$ electrostatic interactions as well as for their large surface areas [7-9]. Therefore, they have received considerable attention for usage in analytical chemistry and environmental remediation [10]. Multi-walled carbon nanotubes (MWCNTs) were the first observed CNTs involving of up to several tens of graphite shells [11]. The sorption capability of MWCNTs is related mainly to the functional groups attached on its surface [12]. Generations of functional groups on the surface carbon nanotubes improves the reactivity and provides active sites for further chemical modifications [13]. Many researchers have developed amino [10,14] and thiol [15-18] functionalization on carbon-based adsorbents and CNTs in order to increase the adsorption capacity and removal efficiency of heavy metals and organic compounds. Among these functional groups, the thiols have an excellent binding ability to some metals such as silver, mercury, copper, nickel and zinc [18,19]. So far, integrated existence of amino and thiol functional groups on the surface of CNTs has not been reported and nor as having been applied as adsorbent for heavy metals.

In the present study, we prepared new integrated amino and thiol functional groups on the MWCNT surface for removal of mercury ions from an aqueous solution. The As-synthesized products were characterized by Fourier transform infrared spectroscopy (FT-IR), thermogravimetric analysis (TGA), X-ray photoelectron spectroscopy (XPS) and scanning electron microscope (SEM). Adsorption of mercury ions from aqueous solution was carried out in batch and continuous systems. The factors affecting the adsorption of $\mathrm{Hg}(\mathrm{II})$ onto the functionalized MWCNTs $(\mathrm{pH}$, ion concentration, feed flow rate, temperature, adsorbent dosage and bed height) were investigated. The data thus obtained were fitted with the Freundlich and Langmuir isotherm models in the batch system and with Yan and Thomas models in the 
continuous mode. The thermodynamic properties, including enthalpy, entropy and Gibbs free energy, of the functionalized MWCNTs were determined from the experimental data. Desorption and recovery of $\mathrm{Hg}$ (II) was also studied for the subsequent recycling. Finally, the capability of thiolated MWCNTs for the removal of $\mathrm{Hg}(\mathrm{II})$ ion from chloralkali wastewater was investigated.

\section{Experimental}

\subsection{Materials and reagents}

MWCNTs were obtained from Timesnano Chinese Academy of Sciences Company. The purity was more than $95 \%$, outside diameter (OD) 20-30 nm, inside diameter (ID) 5-10 nm, length 10$30 \mu \mathrm{m}$, specific surface area (SSA) more than $110 \mathrm{~m}^{2} / \mathrm{g}$, density $0.28 \mathrm{~g} / \mathrm{cm}^{3}$ and electrical conductivity (EC) more than $100 \mathrm{~s} / \mathrm{cm}$. 1,5-diphenylthiocarbazone (Dithizone), hydrochloric acid $(37 \% \mathrm{HCl})$, methanol, ethanol, tetrahydrofuran (THF), $\mathrm{HgCl}_{2}$, ethylenediamine (EDA), concentrated $\mathrm{H}_{2} \mathrm{SO}_{4}$ and $\mathrm{HNO}_{3}$ acids, 2,4,6-trichloro-1,3,5-triazine (cyanuric chloride), n,n-diisopropylethylamine (DIPEA), n,n-dicyclohexylcarbodiimide (DCC) and cetyltrimethylammonium bromide (CTAB) obtained from Merck (Germany). The sodium 2mercaptoethanol was prepared controlled conditions by reacting metallic sodium with 2 mercaptoethanol (from Merck).

\subsection{Synthesis process}

\subsection{1. $\mathrm{MWCNTS}-\mathrm{COOH}$}

Raw-MWCNT (5 g) was treated with $10 \% \mathrm{HCl}$ for $3 \mathrm{~h}$ and 15 min sonication $(180 \mathrm{~W}, 53 \mathrm{kHz}$,) to remove impurities such as metal particles, residual catalysts and amorphous carbons in the stage of synthesis (Fig. 1-a). Then the sample was filtered and washed many successive times 
with distilled water to reach a neutral $\mathrm{pH}$. In order to chemically oxidize and prepare the carboxylated MWCNTs (MWCNTs-COOH), the sample was suspended in $400 \mathrm{ml} 10 \mathrm{~N} \mathrm{H}_{2} \mathrm{SO}_{4}$ and $\mathrm{HNO}_{3}\left(3: 1\right.$ by volume) and refluxed at $175{ }^{\circ} \mathrm{C}$ for $18 \mathrm{~h}$ in Teflon flask, then filtered and washed with hot distilled water until the $\mathrm{pH}$ was neutral, and dried at $180{ }^{\circ} \mathrm{C}$ for $1 \mathrm{~h}$ (Fig. 1- b) [20] .

\subsubsection{MWCNTs-EDA}

For synthesis of the amino modified MWCNTs-EDA, $4 \mathrm{~g}$ of MWCNTs-COOH was placed in a $150 \mathrm{ml}$ EDA solution while stirring at $100 \mathrm{rpm}$ and temperature of $25^{\circ} \mathrm{C}$, then $5 \mathrm{~g}$ of DCC was added and refluxed for $48 \mathrm{~h}$ at $78{ }^{\circ} \mathrm{C}$. The product was passed through a filter paper and washed with ethanol and dried at $80{ }^{\circ} \mathrm{C}$ for $8 \mathrm{~h}$ (Fig. 1- c) [21].

\subsubsection{MWCNTs-triazine}

In order to blend the triazine into the MWCNTs-EDA, $8.86 \mathrm{~g}$ of cyanuric chloride was dissolved in $480 \mathrm{ml}$ of THF and then $11.5 \mathrm{ml}$ of DIPEA was added and stirred at $0{ }^{\circ} \mathrm{C}$ for $3 \mathrm{~h}$ under argon atmosphere. Then $3 \mathrm{~g}$ of MWCNTs-EDA was added to this mixture and stirred at $0{ }^{\circ} \mathrm{C}$ for $48 \mathrm{~h}$ under argon atmosphere; during this reaction time the chlorine atom in cyanuric chloride was substituted by the amine group in EDA and the released $\mathrm{HCl}$ was trapped by DIPEA. Then the sample was filtered and washed with dried THF repeatedly to remove the excess cyanuric chloride and dried at $80{ }^{\circ} \mathrm{C}$ for $8 \mathrm{~h}$ (Fig. 1- d) [22]. The prepared product denoted MWCNTstriazine.

\subsubsection{MWCNTs-SH}


The aromatic triazine ring in the MWCNTs-triazine has two chlorine atoms which can be substituted by thiol functional groups. With that in mind, $25 \mathrm{ml}$ of sodium 2-mercaptoethanol was mixed with $30 \mathrm{ml}$ methanol, then $2 \mathrm{~g}$ of MWCNTs-triazine was added to the mixture and refluxed at $50{ }^{\circ} \mathrm{C}$ for $12 \mathrm{~h}$, stirring at low speed. The sample was filtered and rinsed with methanol and dried at $80{ }^{\circ} \mathrm{C}$ for $3 \mathrm{~h}$ (Fig. 1- e). The thiolated product was denoted as MWCNTsSH.

\subsection{Characterization of adsorbents}

The FT-IR spectra were recorded (Shimadzu FT-IR 8400s spectrometer, Japan) in the range of 500-4000 $\mathrm{cm}^{-1}$ and TGA was also carried out (Rheometric Scientific, STA 1500, USA) from an ambient temperature to $700{ }^{\circ} \mathrm{C}$ in nitrogen atmosphere using a heating rate of $10{ }^{\circ} \mathrm{C} / \mathrm{min}$. The XPS was used to analyze the functionalized MWCNTs by a twin anode XR3E2 x-ray source system (8025-BesTec, Germany). The surface morphologies of the MWCNTs, MWCNTs-

COOH, MWCNTs-EDA, MWCNTs-triazine and MWCNTs-SH were characterized using SEM images (Hitachi S-4160, Japan, 1996) at accelerating voltage of $20 \mathrm{kV}$.

\subsection{Batch adsorption experiments}

Batch adsorption experiments were conducted in $250 \mathrm{ml}$ conical flasks containing $100 \mathrm{ml}$ of $\mathrm{Hg}$ (II) ion solution stirring at $200 \mathrm{rpm}$ and room temperature of $25{ }^{\circ} \mathrm{C}$. The equilibrium study was carried out by sampling at different time intervals and equilibrium was assumed at 60 min. The samples were filtered by a $0.42 \mu \mathrm{m}$ pore size paper filter. A stock solution of $1000 \mathrm{mg} / \mathrm{l}$ of $\mathrm{Hg}$ (II) was prepared by an exact amount of $\mathrm{HgCl}_{2}$ in deionized water $(\mathrm{EC}<0.05 \mu \mathrm{S} / \mathrm{m}$ ), diluting daily to the desired concentration. The $\mathrm{Hg}(\mathrm{II})$ concentrations in solution was measured by 
spectrophotometric method [23]. The removal efficiency of $\mathrm{Hg}(\mathrm{II})$ ion was calculated by the following equation:

$R=\frac{C_{o}-C_{t}}{C_{o}} \times 100$

where $R$ is the removal efficiency of the $\mathrm{Hg}(\mathrm{II}), C_{0}$ the initial concentration and $C_{t}$ the final concentration $\mathrm{Hg}(\mathrm{II})$ in $\mathrm{mg} / \mathrm{l}$ at $t$ time. The adsorption capacity of the adsorbent at equilibrium was calculated by the following equation:

$q_{e}=\frac{\left(C_{o}-C_{o}\right) V}{W}$

where $q_{e}$ is the equilibrium adsorption capacity of the adsorbent in $\mathrm{mg} / \mathrm{g}, C_{0}$ the initial concentration in $\mathrm{mg} / \mathrm{l}$ and $C_{e}$ the equilibrium concentration of $\mathrm{Hg}(\mathrm{II})$ in $\mathrm{mg} / \mathrm{l}, V$ the volume in $\mathrm{L}$ of $\mathrm{Hg}$ (II) solution and $W$ the weight in $\mathrm{g}$ of the adsorbent. The analyses were done in duplicate with the average values reported.

\subsubsection{Effect of the adsorbent dose}

In the batch experiments, the effects of the dose of the adsorbent $(100,200,400$ and $600 \mathrm{mg} / \mathrm{l})$ on adsorption of $\mathrm{Hg}(\mathrm{II})$ at $10 \mathrm{mg} / \mathrm{l}$ were studied. The $\mathrm{pH}$ of the working solution was adjusted to 7 by $0.1 \mathrm{M} \mathrm{NaOH}$. For all experiments, fresh diluted ion solutions were prepared daily.

\subsubsection{Effect of the solution $p H$}

The effect of a different $\mathrm{pH}$ of the initial solution on adsorption was investigated in $\mathrm{pH}$ range of 2 to 8 by adding $0.1 \mathrm{M} \mathrm{HNO}_{3}$ and $0.1 \mathrm{M} \mathrm{NaOH}$ solution. The working volume was $100 \mathrm{ml}$, the adsorbent dose and the ion concentration was 400 and $10 \mathrm{mg} / \mathrm{l}$, respectively. The samples 
contained $250 \mathrm{ml}$ conical flasks were stirred at $200 \mathrm{rpm}$ to reach equilibrium. The concentration of the remaining $\mathrm{Hg}(\mathrm{II})$ ion was measured after filtration at designed intervals.

\subsubsection{Effect of temperature}

The effect of temperature $\left(15,25,35\right.$ and $\left.45^{\circ} \mathrm{C}\right)$ on $\mathrm{Hg}(\mathrm{II})$ adsorption was studied with $40 \mathrm{mg}$ of MWCNTs-SH in $100 \mathrm{ml}$ of $40 \mathrm{mg} / \mathrm{l}$ metal ion solution at $\mathrm{pH} 6$.

\subsection{Adsorption isotherms}

A study to determine the relationship between the $\mathrm{Hg}(\mathrm{II})$ ion adsorbed on MWCNTs-SH and those remaining in the aqueous phase was conducted. All experiments were carried out with the various initial $\mathrm{Hg}(\mathrm{II})$ concentrations $(5,10,20,40,80$ and $100 \mathrm{mg} / \mathrm{l})$ in conditions of: fixed amount of absorbent $40 \mathrm{mg}$ per $100 \mathrm{ml}$ solution, constant $\mathrm{pH} 6$, room temperature $\left(25^{\circ} \mathrm{C}\right)$ and $200 \mathrm{rpm}$ agitation speed. Contact time was $60 \mathrm{~min}$ for all equilibrium conditions. The isotherm data were correlated with the Freundlich and Langmuir models. The Langmuir isotherm is based on a monolayer sorption of metal ion on the surface of the adsorbent and is described by the following equation [24]:

$q_{e}=\frac{q_{m} b C_{e}}{1+b C_{e}}$

where, $q_{e}$ is the adsorption capacity of the adsorbent in $\mathrm{mg} / \mathrm{g}$ and $C_{e}$ the concentration of metal ion in $\mathrm{mg} / \mathrm{l}$ at equilibrium. The $q_{m}$ is the maximum adsorption capacity of the metal monolayer in $\mathrm{mg} / \mathrm{g}$, and $b$ the constant that refers to the bonding energy of adsorption in $1 / \mathrm{mg}$. The Freundlich isotherm model is considered to be appropriate for describing both multilayer sorption and sorption on heterogeneous surfaces. The Freundlich model can be expressed by the following equation [22]: 
$q_{e}=K_{f} C_{e}^{1 / n}$

where, $q_{e}$ is the equilibrium adsorption capacity of the adsorbent in $\mathrm{mg} / \mathrm{g}, C_{e}$ the liquid phase concentration in $\mathrm{mg} / \mathrm{l}$ at equilibrium, $K_{f}$ the constant related to the adsorption capacity of the adsorbent and $n$ the empirical constant depicting the intensity of adsorption which varies with the heterogeneity of the adsorbent. The greater is the value of $n$ the better its adsorption capacity. The nonlinear regression analysis was carried out with SigmaPlot software (SigmaPlot 10.0, USA) in order to predict both the $K_{f}$ and the $n$ parameters.

\subsection{Kinetic studies}

The kinetic studies were carried out using $40 \mathrm{mg}$ of MWCNTs-SH in $100 \mathrm{ml}$ of different concentrations $(5,10,20,40,80$ and $100 \mathrm{mg} / \mathrm{l})$ of $\mathrm{Hg}(\mathrm{II})$ metal ion solutions at $\mathrm{pH} 6$. In order to describe the kinetic process between aqueous and solid phase, the pseudo-first-order rate was used for surface adsorption of $\mathrm{Hg}$ (II) ion on MWCNTs-SH. This model is presented by Lagergren as follows [25]:

$$
\log \left(q_{e}-q_{t}\right)=\log q_{e}-\frac{k_{1}}{2.303} t
$$

The pseudo-second-order rate equation presented by Ho to describe the kinetic adsorption of divalent metal ion onto an absorbent is expressed as follows [26]:

$$
\frac{t}{q_{t}}=\frac{1}{k_{2} q_{e}^{2}}+\frac{t}{q_{e}}
$$

where $q_{e}$ and $q_{t}$ are the amount of adsorbed metal ion in $\mathrm{mg} / \mathrm{g}$ on the adsorbent, at equilibrium and time $t$, respectively, while $k_{1}$ in $\min ^{-1}$ and $k_{2} \mathrm{gmg}^{-1} \mathrm{~min}^{-1}$ are the rate constants of first- and second-order adsorption, respectively [27,28]. 


\subsection{Adsorption thermodynamics}

The adsorption studies were conducted at different temperatures $\left(15,25,35\right.$, and $\left.45{ }^{\circ} \mathrm{C}\right)$ with 40 $\mathrm{mg} / \mathrm{l}$ of $\mathrm{Hg}(\mathrm{II})$ ion concentration for investigating the thermodynamic parameters by calculating the free energy of Gibbs $\left(\Delta \mathrm{G}^{\mathrm{o}}\right)$ according to the following equation [29]:

$\operatorname{Ln} K_{d}=\frac{\Delta S^{o}}{R}-\frac{\Delta H^{o}}{R T}$

where the values of $\Delta \mathrm{H}^{\mathrm{o}}$ (change in enthalpy in $\mathrm{J} \mathrm{mol}^{-1}$ ) and $\Delta \mathrm{S}^{\mathrm{o}}$ (change in entropy in $\mathrm{J}$ $\mathrm{mol}^{-1} \mathrm{~K}^{-1}$ ) are obtained from the slope and intercept of $L n k_{d}$ vs. $1 / T$ plot, $T$ is the temperature in $\mathrm{K}$ and $R$ the universal gas constant $\left(8.314 \mathrm{Jmol}^{-1} \mathrm{~K}^{-1}\right)$. The distribution coefficient $\left(k_{d}\right)$ is calculated from the initial and the equilibrium concentrations $\left(C_{0}\right.$ and $\left.C_{e}\right)$ of the metal ion [7]:

$k_{d}=\frac{C_{o}-C_{e}}{C_{e}} \times \frac{V}{W}$

where, $V$ is the working volume in $\mathrm{L}$ and $W$ the adsorbent mass in $\mathrm{g}$. The $\Delta \mathrm{G}^{\mathrm{o}}$ is the change in Gibbs free energy in $\mathrm{J} \mathrm{mol}^{-1}$, calculated according to the following equation [29]:

$\Delta G^{o}=\Delta H^{o}-T \Delta S^{o}$

\subsection{Fixed bed column adsorption studies}

The adsorption capability of MWCNTs-SH for removal of $\mathrm{Hg}(\mathrm{II})$ ion in solution was studied using a fixed-bed glass column in the form of a lab scale apparatus with an inside diameter of 5 mm. Fig 2 demonstrates the schematic of lab scale apparatus of continuous adsorption. As the figure shows, the prepared solution containing $\mathrm{Hg}(\mathrm{II})$ ion was passed through the column using a peristaltic pump (pump drive 5101, Heidolph, Germany) in upward mode. The experiments were carried out at various bed heights $(7,14$ and $21 \mathrm{~mm})$ of MWCNTs-SH, at various influent flow rates $(1,1.5$ and $2 \mathrm{ml} / \mathrm{min})$ and various initial $\mathrm{Hg}$ (II) ion concentrations (20, 40 and $60 \mathrm{mg} / \mathrm{l})$, at 
$\mathrm{pH} 6$ and room temperature. These conditions were chosen according to optimum conditions obtained in the batch studies. The effluent samples were collected at appropriate time intervals.

\subsubsection{Fixed bed column data analysis and modeling}

The effluent concentration trend versus the time profile gave the breakthrough curve. The breakthrough time, $t_{b}$, is considered to be when the metal concentration in the effluent $\left(C_{e f f}\right)$ reaches about $5 \%$ of the influent concentration $\left(C_{o}\right)$, representing the still active column. The exhausting time, $t_{e}$, is assumed when the metal concentration in the effluent reaches $95 \%$ of the influent concentration. The area surrounded by the breakthrough curve represents the total metal ion mass adsorbed $\left(q_{\text {total }}, \mathrm{mg}\right)$ which is evaluated by the following equation:

$q_{\text {total }}=\frac{Q C_{o}}{1000} \int_{t=0}^{t=t_{\text {tolal }}}\left(1-\frac{C_{\text {eff }}}{C_{o}}\right) d t$

where $\left(1-C_{e f f} / C_{0}\right)$ is the concentration of metal ion absorbed $(\mathrm{mg} / \mathrm{l})$ and $Q$ the flow rate $(\mathrm{ml} / \mathrm{min})$ that can be determined by Eq. (11).

$Q=\frac{V_{\text {eff }}}{t_{\text {total }}}$

The total amount metal ion passed through the column (mg) can be obtained from the Eq. (12) and the total removed metal evaluated by dividing the metal mass absorbed $\left(q_{\text {total }}\right)$ by the total amount of metal ion passed the column ( $\left.m_{\text {total }}\right)$, as shown in Eq. (13):

$$
\begin{aligned}
& m_{\text {total }}=\frac{C_{o} \times Q \times t_{e}}{1000} \\
& R=\frac{q_{\text {total }}}{m_{\text {total }}} \times 100
\end{aligned}
$$


The equilibrium adsorption capacity, $q_{e}(\mathrm{mg} / \mathrm{g})$, and the equilibrium metal concentration, $C_{e}$ $(\mathrm{mg} / \mathrm{l})$, can be obtained from the following equations, respectively:

$$
\begin{aligned}
q_{e} & =\frac{q_{\text {total }}}{m} \\
C_{e} & =\frac{m_{\text {total }}-q_{\text {total }}}{V_{\text {eff }}} \times 1000
\end{aligned}
$$

where $m$ is the adsorbent mass ( $\mathrm{g}$ ). The mass transfer zone (MTZ) is the region of the bed where most of the adsorption occurs and moves up through the bed column in time to be evaluated by Eq. (16) [22]:

$$
M T Z=L \frac{t_{e}-t_{b}}{t_{e}}
$$

where $L$ is the bed height $(\mathrm{cm}), t_{b}$ and $t_{e}$ are the time (min) required to achieve the breakthrough point and the exhaust point, respectively.

Successful designing of the column adsorption needs to be able to predict the concentration-time breakthrough curve for the effluent. The maximum capability of an adsorbent is also required in the design. The Thomas model (Thomas, 1948) is used traditionally to achieve this purpose and expressed as follows [30]:

$$
\frac{C_{e f f}}{C_{o}}=\frac{1}{1+\exp \left(\frac{k_{T}}{Q}\left(q_{T} M-C_{o} V\right)\right)}
$$

where $C_{\mathrm{e}}(\mathrm{mg} / \mathrm{l})$ is the metal ion concentration in effluent, $C_{0}$ the influent metal ion concentration in $\mathrm{mg} / \mathrm{l}, k_{\mathrm{T}}$ the Thomas rate constant in $\mathrm{ml} / \mathrm{min} . \mathrm{mg}, q_{\mathrm{T}}$ the maximum solid-phase concentration of solution in $\mathrm{mg} / \mathrm{g}, M$ the mass of the adsorbent in $\mathrm{g}, V$ the throughput volume in $\mathrm{ml}$ and $Q$ the influent flow rate in $\mathrm{ml} / \mathrm{min}$. The Yan model is an empirical equation overcoming the deficiencies in the Thomas model, especially its serious deficit in predicting the effluent 
concentration at time zero. It was found to define the breakthrough curve better in a fixed bed column. This equation is expressed as follows [31]:

$$
\frac{C_{e f f}}{C_{o}}=1-\frac{1}{\left(\frac{Q C_{o} t}{q_{Y} M}\right)^{a}}
$$

where $q_{\mathrm{Y}}$ is the maximum adsorption capacity $(\mathrm{mg} / \mathrm{g})$ of adsorbent estimated by the Yan model and $a$ the constant coefficient.

\subsection{Batch desorption study}

Any prepared adsorbent must be renewable in practice, or synthetized MWCNTs-SH should also be reusable several times in adsorption-desorption cycles. Reusability of MWCNTs-SH was determined in five adsorption-desorption cycles. To optimize the type and concentration of the acid, the experiments were carried out with different concentrations $(0.1,0.3$ and $0.5 \mathrm{M})$ of $\mathrm{HCl}$, $\mathrm{H}_{2} \mathrm{SO}_{4}$ and $\mathrm{HNO}_{3}$. Then the acid with more efficiency in desorption of loaded $\mathrm{Hg}$ (II) ion on the MWCNTs-SH was selected. After each cycle the regenerated adsorbent was washed twice by distilled water and centrifuged to remove the remainder ion, from the adsorbent. The metal recovery was calculated by the following Eq. (19) [32]:

$$
\text { metal recovery }=\frac{\text { Amount of metal ions desorbed }}{\text { Amount of metal ions adsorbed }} \times 100
$$

\subsection{Real wastewater study}

In order to survey capability of the prepared adsorbents for removal of $\mathrm{Hg}$ (II) from actual wastewater, some batch experiments were conducted on chloralkali wastewater. The wastewater sample was taken from effluent sewage of wastewater treatment plan of petrochemical 
chloralkali unit of Mahshahr, Iran. An sufficient amount of nitric acid was added to sample to prevent adsorption of mercury ions by the plastic walls of container. The sample was held in a cooled flask with ice bag and transported to laboratory for study. After adjusting the $\mathrm{pH}$ to 6,100 $\mathrm{ml}$ of sample was placed in four $250 \mathrm{ml}$ conical flask and $20 \mathrm{mg}$ of each adsorbent (MWCNTs, MWCNTs-COOH, MWCNTs-EDA and MWCNTs-SH) was added and stirred for 60 min. After than the $\mathrm{Hg}(\mathrm{II})$ content of all samples was determined by an inductively coupled plasma mass (ICP-Ms) method (PerkinElmer, Optima 7300 DV, USA).

\section{Results and discussion}

\subsection{Characterization of adsorbents}

The FT-IR peaks in the range of 500-4000 $\mathrm{cm}^{-1}$, related to pristine and functionalized MWCNTs, are recorded in Fig. 3-a. The $\mathrm{H}_{2} \mathrm{SO}_{4}-\mathrm{HNO}_{3}$ treatment introduces the carboxyl group on the MWCNTs during oxidation. The presence of peaks at $\approx 3438$ and $\approx 1726 \mathrm{~cm}^{-1}$ are related to the stretching vibrations of $v(\mathrm{OH})$ and $v(\mathrm{C}=\mathrm{O})$ of the carboxyl groups $(\mathrm{COOH})$, respectively, [10] which become stronger and deeper in the MWCNTs-COOH rather than the MWCNTs. Symmetric and asymmetric methylene stretching bands at $\approx 2850$ and $\approx 2920 \mathrm{~cm}^{-1}$, respectively, are observed to be present in the MWCNTs and MWCNTs-COOH. It is assumed that defective sites on the sidewall of MWCNTs contain these groups [20]. The peak at $\approx 1097 \mathrm{~cm}^{-1}$ is assigned to the $v(\mathrm{C}-\mathrm{O})$ stretching vibration [10] which becomes sharper in the MWCNTs-COOH compared to the MWCNTs and disappears after amine functionalization. A peak at $\approx 3378 \mathrm{~cm}^{-1}$ overlapping with the stretching vibration of $v(-\mathrm{OH})$ in the MWCNTs-EDA is due to the $-\mathrm{NH}_{2}$ stretching of the amine group $[10,33]$ that confirms the successful engulfing of the EDA to carboxyl groups. In the MWCNTs-triazine the three successive peaks from $\approx 800$ to $\approx 1300 \mathrm{~cm}^{-1}$ 
are due to incorporation of the melamine-based molecule to EDA tails of the MWCNTs-EDA. The $\mathrm{C}-\mathrm{Cl}$ and $\mathrm{C}-\mathrm{N}$ bond stretchings at $\approx 763$ and $\approx 1180 \mathrm{~cm}^{-1}$, respectively, are detectable $[34,35]$. Those at $\approx 1531$ and $\approx 1492 \mathrm{~cm}^{-1}$ and at $\approx 1178 \mathrm{~cm}^{-1}$ were assigned to $\mathrm{C}=\mathrm{N}$ and $\mathrm{C}-\mathrm{N}$ groups in the triazine ring, respectively [36]. The new weak peak at $\approx 2668 \mathrm{~cm}^{-1}$ in MWCNTs-SH may be attributed to the $\mathrm{S}-\mathrm{H}$ bond vibration.

It should be mentioned that the $\mathrm{S}-\mathrm{S}$ or $\mathrm{C}=\mathrm{S}$ bond that maybe appeared in thiol functionalization were observed [15], but hardly detectable in the FT-IR spectra. Therefore, the XPS was used to confirm the thiolation of the MWCNTs. In Fig. 3-b, a series of XPS survey spectra for the MWCNTs-EDA and MWCNTs-SH are shown. The XPS data show the peaks corresponding to $\mathrm{C}, \mathrm{O}$ and N1s and S2p. The peaks were calibrated with a value of $\mathrm{C} 1 \mathrm{~s}$ peak at $284.5 \mathrm{eV}$ [16]. The C1s peaks are derived from graphitic and aromatic groups, like phenolic, hydroxyl or ether groups, and carbonyl and carboxylic or ester groups. The O1s peak at $533.0 \mathrm{eV}$ includes oxygen in carbonyl groups, hydroxyl or ethers, anhydride, lactone, or carboxylic acids. The N1s peaks were from nitrogen atoms in the functional groups of $\mathrm{NH}-, \mathrm{N}-\mathrm{O},-\mathrm{CON}$ or $\mathrm{CONH}_{2}$ at 400.0 $401.5 \mathrm{eV}$ in MWCNTs-EDA [37]. With increase in nitrogen atoms in the MWCNTs-SH, related to the triazine ring, the nitrogen peak there becomes broader $(397.0-401.5 \mathrm{eV})$ compared to that in the MWCNTs-EDA and they split due to the different chemical bonds of $-\mathrm{O}-\mathrm{C}-\mathrm{N}$ or $-\mathrm{O}-$ $\mathrm{C}=\mathrm{N}$ groups. A S2p peak appeared in the MWCNTs-SH spectrum at $163.7 \mathrm{eV}$, which is due to the $-\mathrm{CH}_{2}-\mathrm{SH}$ bond $[38,39]$, confirming the successful synthesis of the MWCNTs-SH.

Fig. 3-c shows the TGA curves. The samples were heated at a rate of $10^{\circ} \mathrm{C} / \mathrm{min}$ in a nitrogen atmosphere to $700{ }^{\circ} \mathrm{C}$. The pristine MWCNTs did not have a noticeable weight loss until the temperature reached $500{ }^{\circ} \mathrm{C}$, due to the pretreatment of pristine MWCNTs for removal of impurities with $10 \% \mathrm{HCl}$, but afterwards they decomposed sharply from 500 to $700{ }^{\circ} \mathrm{C}$. The loss 
of weight of MWCNTs-EDA occurred at lower temperatures compared with pristine MWCNTs because most of the organic functional moieties on the MWCNTs-EDA are thermally unstable [10]. The most weight loss was achieved at 250 to $300{ }^{\circ} \mathrm{C}(1.4 \%)$ and the total thermal decomposition from 200 to $500{ }^{\circ} \mathrm{C}$ was $4.33 \%$ attributed to dislocations of carbon materials, covalently bonded EDA and oxygenated groups on the surface of MWCNTs-EDA. In the same manner the most weight loss of MWCNTs-SH occurred at 250 to $300{ }^{\circ} \mathrm{C}(3.38 \%)$ and the total mass loss of $8.7 \%$ happened in the temperature range of 200 to $500{ }^{\circ} \mathrm{C}$. The greater weight loss of MWCNTs-SH indicates the presence of amine and thiol functional groups on the surface of MWCNTs. A comparison of SEM images of MWCNTs, MWCNTs-COOH, MWCNTs-EDA, MWCNTs-triazine and MWCNTs-SH are shown in Fig. 3-d. All samples were sputtered with gold before imaging. As shown in Fig. 3-d, no changes in morphology has occurred in all samples where the nanotubes do not appear to be damaged or shortened during oxidation at severe and harsh experimental conditions. The images show that most of the tubes are in parallel arrangement to one another after treatments. This may be due to strong intertubular electrostatic interactions between surface functional groups. On the other hands, the hydrophobic surface of MWCNTs leading to repulsion among tubes, resulted in a random arrangement of nanotubes [40]. Furthermore, it is noticeable that there are more open ends (bright patches) on the MWCNTs-COOH compared to raw MWCNTs, suggesting that nanotubes become more active at the ends and sidewalls [41]. Created defect sites and covalently attached functional groups, especially in amine modified cases (MWCNTs-EDA and MWCNTs-triazine), can cause a reduction in electric conductivity of nanotubes, which may be the reason for the blurring shape of the images and reduction of the contrast and resolution [42]. 


\subsection{Adsorption of $\mathrm{Hg}(\mathrm{II})$ metal ion in batch system}

\subsubsection{Effect of adsorbent dose}

The batch experiments were carried out to compare the efficiency of different adsorbents for $\mathrm{Hg}$ (II) ion removal, a comparison of which for five adsorbents at different doses is depicted in

Fig. 4. According to these data, the MWCNTs-SH can be considered to be a more effective adsorbent than the others. Furthermore, increasing the adsorbent dose increases the ion removal percentage due to a boost in the available fresh sites on the absorbent. The tendency of $\mathrm{Hg}(\mathrm{II})$ to bind to the thiol functional group has been proved [43]. The $\mathrm{Hg}(\mathrm{II}), \mathrm{Cd}(\mathrm{II})$ and $\mathrm{Pb}$ (II) are metal ions with low-charge density, considered soft acids that form strong covalent bonds to soft bases such as sulfur [44]. Although carboxylated and amino modified MWCNTs have been used for removal of divalent metals $[10,21]$, no other metal forms as strong a covalent bond with a thiol functional group as mercury ion does $\left(200 \mathrm{~kJ} \mathrm{~mol}^{-1}\right)$. It is well-known that the ligands containing aromatic backbones with two additional thiol arms can bind the $\mathrm{Hg}$ in a linear $\mathrm{S}-\mathrm{Hg}-\mathrm{S}$ arrangement [45]. These types of ligands are effective at removing mercury ions from aqueous solutions. Furthermore, in our synthesized MWCNTs-SH, two thiol functional groups have been attached to alkyl chains that provide the high flexibility to achieve the linear $\mathrm{S}-\mathrm{Hg}-\mathrm{S}$ arrangement (Fig. 1-e).

\subsubsection{Effect of solution $p H$}

The $\mathrm{pH}$ of the solution plays an important role on the adsorption of ion metals. In order to determine the effect of $\mathrm{pH}$ on the $\mathrm{Hg}$ (II) ion removal by MWCNT-SH, some experiments were carried out with different $\mathrm{pH}$ values while the other parameters were constant. As is shown in 
Fig. 5, the $\mathrm{Hg}$ (II) removal increases from $9.8 \%$ to $92 \%$ with increase in the $\mathrm{pH}$ from 2 to 8 , respectively. The solution $\mathrm{pH}$ has a different effect on adsorption depending on the type of adsorbent and functional groups. The removal of mercury ions by powdered activated carbon revealed that the removal efficiency decreases with an increasing $\mathrm{pH}$ [3]. The reaction mechanism of the SH functional group and mercury ions species are formulated as equations (20) and (21) [43].

$2 \mathrm{R}-\mathrm{SH}+\mathrm{Hg}^{2+} \rightarrow \mathrm{R}-\mathrm{S}-\mathrm{Hg}-\mathrm{S}-\mathrm{R}+2 \mathrm{H}^{+}$

$\mathrm{R}-\mathrm{SH}+\mathrm{HgCl}^{+} \rightarrow \mathrm{R}-\mathrm{S}-\mathrm{HgCl}+\mathrm{H}^{+}$

It can be discerned from these reactions that increasing the $\mathrm{OH}^{-}$lead to consumption of $\mathrm{H}^{+}$in the solution, allowing the reactions to proceed properly. In contrast, increasing the $\mathrm{H}^{+}$in the solution causes competition between hydrogen and metal ion for active binding sites, whereby the removal percentage decreases. Furthermore, the more preferable species of metal ion at higher $\mathrm{pH}$ are the $\mathrm{Hg}(\mathrm{OH})_{3}{ }^{-}, \mathrm{Hg}(\mathrm{OH})_{2}$ and $\mathrm{Hg}(\mathrm{OH})^{+}$compound forms, which have smaller effective size and higher mobility than $\mathrm{Hg}(\mathrm{II})[18,46,47]$.

\subsection{Adsorption isotherms}

Adsorption isotherms contain certain constant parameters expressing the surface properties and affinity of the adsorbent, making it possible to evaluate the adsorption capacity of the adsorbent for metal ion. The nonlinear Langmuir and Freundlich adsorption isotherms of the $\mathrm{Hg}(\mathrm{II})$ ion (evaluated at the adsorbent dose of $400 \mathrm{mg} / \mathrm{l}$ and $25{ }^{\circ} \mathrm{C}$ temperature) are shown in Fig. 6. The parameters of Langmuir and Freundlich isotherms $\left(b, q_{m}, n\right.$ and $\left.k_{f}\right)$ and the nonlinear regression correlation coefficients $\left(R^{2}\right)$ are given in Table 1. A sharp initial slope in both isotherms indicate that the efficiency of the adsorbent is high in low $\mathrm{Hg}(\mathrm{II})$ concentrations and it decreases with an 
increase in the metal ion concentration due to the saturation of active sites on the adsorbent surface. As shown in Table 1, the correlation coefficients indicate that the adsorption tended to be fitted better by the Langmuir $\left(R^{2}=0.945\right)$ than the Freundlich model $\left(R^{2}=0.926\right)$. Thus, the adsorption can be described by the Langmuir Isotherm and the metal ion adsorption occurs on an homogeneous surface by monolayer sorption without interaction between the adsorbed ion, whereas the Freundlich model expresses multilayer adsorption with a heterogeneous energetic distribution of active sites with interactions between the adsorbed ion [24]. The maximum adsorption capacity $\left(q_{m}\right)$ obtained with Langmuir was $84.66 \mathrm{mg} / \mathrm{g}$, which is higher than some recently thiolated CNTs such as $65.52 \mathrm{mg} / \mathrm{g}$ with $\mathrm{MPTS}-\mathrm{CNT} / \mathrm{Fe}_{3} \mathrm{O}_{4}[18]$ and $72.8 \mu \mathrm{g} / \mathrm{g}$ with SMWCNTs [46] for $\mathrm{Hg}$ (II) removal.

\subsection{Adsorption thermodynamics}

The effect of temperature on the adsorption of $\mathrm{Hg}(\mathrm{II})$ ion onto MWCNTs-SH has been illustrated by a linear plot of $\ln k_{\mathrm{d}}$ versus $1 / T$ in Fig. 7, and the estimated thermodynamic parameters and correlation coefficients calculated from Eqs. (7-9) are summarized in Table 2. Under the steadystate reaction conditions, the Gibbs free energy $\left(\Delta \mathrm{G}^{0}\right)$ ranges from -3.18 to $-4.59 \mathrm{~kJ} \mathrm{~mol}^{-1}$, and the $\Delta \mathrm{H}^{\mathrm{o}}$ and $\Delta \mathrm{S}^{\mathrm{o}}$ are $-18.12 \mathrm{~kJ} \mathrm{~mol}^{-1}$ and $-0.047 \mathrm{~J} \mathrm{~mol}^{-1} \mathrm{~K}^{-1}$, respectively, indicating that lower temperatures favor spontaneous reaction for $\mathrm{Hg}(\mathrm{II})$ adsorption by MWCNTs-SH. The negative values of $\Delta \mathrm{H}^{0}$ with a decreasing trend of $k_{\mathrm{d}}$ with increasing temperature revealed that the adsorption of $\mathrm{Hg}$ (II) onto the MWCNTs-SH is exothermic. The negative values of $\Delta \mathrm{G}^{\mathrm{o}}$ indicate that the adsorption of $\mathrm{Hg}(\mathrm{II})$ onto MWCNTs-SH is spontaneous. However, the $\Delta \mathrm{G}^{\circ}$ values increase with increasing temperature, indicating that the adsorption is more efficient at lower temperatures. As to whether the adsorption of $\mathrm{Hg}(\mathrm{II})$ onto MWCNTs-SH is chemisorption or 
physisorption, it is noted that the covalent bonding of mercury ion with thiol functional groups releases $200 \mathrm{~kJ} \mathrm{~mol}^{-1}$, and that the change in $\Delta \mathrm{G}^{\circ}$ for physisorption happens at between (-20 and $0 \mathrm{~kJ} \mathrm{~mol}^{-1}$ ), while the physisorption and chemisorption together occur within the range of (20 to $\left.-80 \mathrm{~kJ} \mathrm{~mol}^{-1}\right)$, chemisorption being within the range of (-80 to $\left.-400 \mathrm{~kJ} \mathrm{~mol}^{-1}\right)$ [48]. The obtained $\Delta \mathrm{G}^{\circ}$ values indicate that interactions between $\mathrm{Hg}(\mathrm{II})$ and MWCNTs-SH can be considered as physisorption mechanism. On the other hand, it is accepted that physical adsorption involves an enthalpy change in the range of ( 2 to $\left.21 \mathrm{~kJ} \mathrm{~mol}^{-1}\right)$, while the heat for chemisorption generally falls into a range of $\left(80-200 \mathrm{~kJ} \mathrm{~mol}^{-1}\right)$ [49]. The low value of $\Delta \mathrm{S}^{\circ}$ implies that no noticeable change in entropy occurred during the $\mathrm{Hg}(\mathrm{II})$ adsorption and the negative value of $\Delta \mathrm{S}^{\circ}$ indicates a tendency to lower disorder at the solid-solution interface during adsorption. In addition, it also reflects no occurrence of ion replacement reactions, because the increased entropy of the system could have happened due to release of the ion from the solid surface to the solution [10]. On the other hand, in adsorption processes release of the water molecules produced by ion exchange reactions between the metal ion and the surface functional groups of the adsorbent can increase $\Delta \mathrm{S}^{\circ}[50]$.

\subsection{Desorption}

The desorption efficiency of MWCNTs-SH was evaluated by $\mathrm{HCl}, \mathrm{H}_{2} \mathrm{SO}_{4}$ and $\mathrm{HNO}_{3}$ acid treatment. The $0.5 \mathrm{M} \mathrm{HCl}$ was more effective than other concentrations as well as other acid types. The adsorbent was reused in five successive adsorption-desorption cycles as can be seen in Fig. 8, indicating a loss in the adsorption capacity of $7.2 \%$ for $\mathrm{Hg}(\mathrm{II})$ compared to the initial cycle, revealing a good regeneration capacity of the adsorbent. This is different from what Pillay et al. [46] have reported whereas no desorption was observed in their prepared S-MWCNTs due 
to strong bonding of the $\mathrm{Hg}$ (II) to sulfur functional groups on the adsorbent surfaceand even acid washing was unable to release the mercury ions. . As mentioned before, the MWCNTs-SH prepared in this study contains two free thiol chains that can bind to $\mathrm{Hg}$ (II) in a linear arrangement, depending strongly on the $\mathrm{pH}$ of the solution, whereby desorption can be achieved at low $\mathrm{pH}$. The good desorption rate also confirms that the $\mathrm{Hg}(\mathrm{II})$ adsorption is physisorption.

\subsection{Adsorption kinetics}

Typical kinetic experimental curves for adsorption of $\mathrm{Hg}(\mathrm{II})$ on the MWCNTs-SH in different ion concentrations showed that ion adsorption increases sharply during a short contact time (5 min) and slows down gradually to reach equilibrium (Figure not shown). In order to describe the kinetics for $\mathrm{Hg}(\mathrm{II})$ ion adsorption onto the MWCNTs-SH, the pseudo-first-order and pseudosecond-order kinetics are applied (Figures not shown). The parameters of the kinetic models and the regression correlation coefficients $\left(R^{2}\right)$ are listed in Table 3. The $R^{2}$ values clearly indicate the validity of the pseudo-second-order versus pseudo-first-order kinetics which is not fitted logically. As seen in Table 3, when the initial ion concentration increases from 5 to $100 \mathrm{mg} / \mathrm{l}$, the pseudo-second-order constants $\left(k_{2}\right)$ decrease from 2.05 to $0.0025 \mathrm{~g} / \mathrm{mg} \mathrm{min}$. This indicates that the available active sites on the MWCNTs-SH are saturated rapidly by $\mathrm{Hg}(\mathrm{II})$ ion, furthermore suggesting the possibility of the formation of a monolayer coverage of $\mathrm{Hg}(\mathrm{II})$ onto the adsorbent [2].

\subsection{Adsorption of $\mathrm{Hg}($ II) in fixed bed column}

\subsubsection{Effect of bed height}


Fixed-bed column experiments were conducted using filled columns with MWCNTs-SH for three different bed heights (of 7,14 and $21 \mathrm{~mm}$ ) at a constant flow rate of $1.5 \mathrm{ml} / \mathrm{min}$ and an influent $\mathrm{Hg}$ (II) concentration of $40 \mathrm{mg} / \mathrm{l}$. The breakthrough curves at different bed heights are shown in Fig. 9-a and the breakthrough analysis summarized in Table 4. At a constant flow rate, with increase in the bed height from 7 to $14 \mathrm{~mm}$, the removal percentage increases from 42.46 to $57 \%$ due to more active sites in the column. Also, because the MTZ needs more time to reach the column end, the metal ion have more time to be in contact with the absorbent, but in bed height of $21 \mathrm{~mm}$ no noticeable removal occurs $(53.97 \%)$, because it takes longer for the column to reach exhaustion time, more solution can pass through the column, so the removal obtained is less than that for the bed height of $14 \mathrm{~mm}$. According to Table 4, both the greater $q_{\mathrm{e}}$ (91.37 $\mathrm{mg} / \mathrm{g}$ ) and the removal percentage denote results for the bed height of $14 \mathrm{~mm}$ rather than those of 7 and $21 \mathrm{~mm}$. Thus the optimum bed height can be considered as $14 \mathrm{~mm}$.

\subsubsection{Effect of flow rate}

The breakthrough curves for $\mathrm{Hg}(\mathrm{II})$ at various flow rates (of $1,1.5$ and $2 \mathrm{ml} / \mathrm{min}$ ) through a 7 mm bed height column and an influent concentration of $40 \mathrm{mg} / \mathrm{l}$ are shown in Fig. 9-b and the breakthrough parameters presented in Table 4. These results reveal that with increasing the flow rate from 1 to $2 \mathrm{ml} / \mathrm{min}$, the breakthrough curve shows shorter time to reach the column exhaustion. The breakthrough analysis shows that at the flow rates of $1,1.5$ and $2 \mathrm{ml} / \mathrm{min}$, the $q_{e}$ values are $105.65,76.42$ and $71.47 \mathrm{mg} / \mathrm{g}$ and MTZ values 4.41, 6.35 and $6.79 \mathrm{~mm}$, respectively. By increasing the flow rate, the metal ion do not have enough time to bind to the absorbent as they would have passed the column before reaching equilibrium, so the column active life is significantly reduced [22], and a higher $q_{e}$ obtained at flow rate of $1 \mathrm{ml} / \mathrm{min}$. At the lower flow 
rate $(1 \mathrm{~m} \mathrm{l} / \mathrm{min})$ the MTZ is located in the lower section of the column $(4.41 \mathrm{~mm})$, so the metal ion have enough time to bind to the adsorbent along the column, but at higher flow rates the MTZ shifts to the end of the column, which can diminish the time needed for binding the metal ion.

\subsubsection{Effect of influent metal ion concentration}

The effect of the influent metal ion concentration on the adsorption of the $\mathrm{Hg}(\mathrm{II})$ was investigated by using it in various concentrations (of 20, 40 and $60 \mathrm{mg} / \mathrm{l}$ ) at a constant bed height of $7 \mathrm{~mm}$ and flow rate of $1 \mathrm{ml} / \mathrm{min}$. The results are presented in Fig. 9-c and Table 4. According to the figure, with increase in the initial ion concentration from 20 to $60 \mathrm{mg} / \mathrm{l}$, the column exhaustion occurs faster due to an enhanced dispersion of metal ion along the column, besides

this can have an effect on the MTZ length. As the breakthrough analysis shows in Table 4, the MTZ values obtained for concentrations of 20,40 and $60 \mathrm{mg} / \mathrm{l}$ are 5.46, 4.41 and $4.13 \mathrm{~mm}$, respectively. Increasing the initial ion concentration creates a driving force to diffuse the metal ion from the liquid phase into the surface of the adsorbent, hence the MTZ is shortened. However a higher $q_{e}$ value is obtained with concentration of $40 \mathrm{mg} / \mathrm{l}(105.65 \mathrm{mg} / \mathrm{g})$, but increasing the initial ion concentration further lead to concluding with a larger removal percentage. Thus for concentrations of 20,40 and $60 \mathrm{mg} / \mathrm{l}$, the removal obtained is $55.34,64.03$ and $69.30 \%$, respectively. This trend is due to the decrease in the total passed volume of metal solution through the column with the increase in the influent metal ion concentration, until the column reaches to exhaustion time.

\subsection{Fixed bed column modeling}


The Thomas and Yan models were used for fitting the experimental data in order to determine the rate constant, maximum adsorption capacity and to predict the breakthrough curve for dynamic adsorption of $\operatorname{Hg}(\mathrm{II})$. The breakthrough curves, predicted by the Yan and Thomas models at different bed height, flow rate and various initial concentrations for $\mathrm{Hg}(\mathrm{II})$, are shown in Fig. 9(a-c). All the parameters of the Thomas and Yan models for Hg(II) removal in columns for various conditions are presented in Table 4. As these parameters show, the obtained nonlinear regression correlation coefficients $\left(R^{2}\right)$ from the Yan model (ranging from 0.957 to 0.999 ) compared with those from the Thomas model (ranging from 0.978 to 0.996 ) are slightly higher, except for two cases (see Table 4). From this table, it can be seen that the obtained data were fitted better by the Yan than the Thomas model, but with no significant differences. On the other hand, the difference between the experimental adsorption capacity $\left(q_{e}\right)$ of $\operatorname{Hg}$ (II) and the values predicted by the Thomas model $\left(q_{T h}\right)$ are lower than those by the Yan model $\left(q_{Y}\right)$. Thus the Thomas model is a more suitable kinetic model to describe the $\mathrm{Hg}$ (II) adsorption onto MWCNTs-SH in a fixed-bed column.

\subsection{Chloralkali wastewater adsorption}

In order to survey capability of the prepared adsorbents for removal of $\mathrm{Hg}$ (II) from actual wastewater, some batch experiments were conducted on chloralkali wastewater. Characteristics

of chloralkali wastewater are summarized in Table 5. As the results show, chloralkali wastewater contains a high concentration of different ions, especially of total solids (TS) and EC, which can interfere with adsorption of $\mathrm{Hg}$ ion on the adsorbents. Thus the selectivity of the adsorbent is important. As the Fig. 10 shows, the MWCNTs-SH is a good adsorbent with high 
capability for adsorption of mercury ions (88.7\%) from chloralkali wastewater in comparison with other modified MWCNTs.

\section{Conclusions}

Amino and thiol functional groups of MWCNTs were successfully prepared for the removal of mercury ions from synthetic chloralkali wastewater. The FT-IR, XPS, TGA and SEM analyses confirmed successful entailing the functional groups on the MWCNTs. The experiments revealed that the MWCNTs-SH has a good capability for $\mathrm{Hg}$ (II) ion removal from aqueous solution. At desired conditions of the batch system (pH 6 and adsorbent dose of $400 \mathrm{mg} / \mathrm{l}$ ), the experimental maximum adsorption capacity of MWCNTs-SH for $\mathrm{Hg}(\mathrm{II})$ ion removal was achieved with 84.66 $\mathrm{mg} / \mathrm{g}$ by Langmuir isotherm model. The equilibrium data were fitted by the Langmuir model $\left(R^{2}\right.$ $=0.945)$ better than the Freundlich model $\left(R^{2}=0.926\right)$. In the thermodynamic studies the values for $\Delta \mathrm{H}^{\circ}$ and $\Delta \mathrm{S}^{\circ}$ were obtained as $-18.12 \mathrm{~kJ} \mathrm{~mol}^{-1}$ and $-0.047 \mathrm{~kJ}^{-1} \mathrm{~mol}^{-1} \mathrm{~K}^{-1}$, respectively, indicating an exothermic and spontaneous nature of the adsorption. The physisorption mechanism of adsorption was confirmed by the negative values of $\Delta \mathrm{G}^{\circ}$ increased with increasing of temperature. The kinetic adsorption parameters showed that the overall adsorption can be described better by the pseudo-second-order than the pseudo-first-order kinetic model. The adsorption-desorption experiments showed a small loss in the adsorption capacity of $7.2 \%$ for $\mathrm{Hg}$ (II) after five cycles, indicating a good regeneration capacity of the adsorbent for treating wastewater containing mercury ions. In the continuous mode, effects on the breakthrough curve of bed height, flow rate and initial ion concentration were investigated, while the experimental adsorption capacity reached to $105.65 \mathrm{mg} / \mathrm{g}$. The Thomas model predicted the maximum adsorption capacity better than the Yan model, but logically both models described the 
breakthrough curves in all continuous modes of operation. Finally, we found out that our new synthesized MWCNTs-SH is a good adsorbent for mercury ions removal (by 88.7\%) from chloralkali wastewater.

\section{Acknowledgements}

The authors appreciate the sponsorship of the Ministry of Science, Research and Technology of Iran and the financial support of the Tarbiat Modares University (TMU) by whose grant the present research was made possible. The authors wish also to thank Mrs. Haghdoust (Technical assistant of the Laboratory) for her assistance in laboratory works, and Ellen Vuosalo Tavakoli (University of Mazandaran) for final editing of the English text.

\section{References}

[1] A.M. Starvin, T.P. Rao, Removal and recovery of mercury(II) from hazardous wastes using 1-(2-thiazolylazo)-2-naphthol functionalized activated carbon as solid phase extractant., Journal of Hazardous Materials. 113 (2004) 75-9.

[2] M.F. Yardim, T. Budinova, E. Ekinci, N. Petrov, M. Razvigorova, V. Minkova, Removal of mercury (II) from aqueous solution by activated carbon obtained from furfural., Chemosphere. 52 (2003) 835-41.

[3] M. Zabihi, A. Ahmadpour, A. Asl, Removal of mercury from water by carbonaceous sorbents derived from walnut shell, Journal of Hazardous Materials. 167 (2009) 230-236.

[4] Y. Tian, B. Gao, V.L. Morales, L. Wu, Y. Wang, R. Muñoz-Carpena, et al., Methods of using carbon nanotubes as filter media to remove aqueous heavy metals, Chemical Engineering Journal. 210 (2012) 557-563.

[5] A.M. Starvin, T.P. Rao, Removal and recovery of mercury ( II ) from hazardous wastes using carbon as solid phase extractant, 113 (2004) 75-79.

[6] C.B. Wade, C. Thurman, W. Freas, J. Student, D. Matty, D.K. Mohanty, Preparation and characterization of high efficiency modified activated carbon for the capture of mercury from flue gas in coal-fired power plants, Fuel Processing Technology. 97 (2012) 107-117. 
[7] O. Moradi, K. Zare, M. Monajjemi, M. Yari, H. Aghaie, The Studies of Equilibrium and Thermodynamic Adsorption of $\mathrm{Pb}(\mathrm{II}), \mathrm{Cd}(\mathrm{II})$ and $\mathrm{Cu}$ (II) Ions from Aqueous Solution onto SWCNTs and SWCNT-COOH Surfaces, Fullerenes, Nanotubes and Carbon Nanostructures. 18 (2010) 285-302.

[8] F. Taleshi, A. a Hosseini, Synthesis of uniform $\mathrm{MgO} / \mathrm{CNT}$ nanorods by precipitation method, Journal of Nanostructure in Chemistry. 3 (2012) 4.

[9] M.M. Shokrieh, A. Saeedi, M. Chitsazzadeh, Mechanical properties of multi-walled carbon nanotube/polyester nanocomposites, Journal of Nanostructure in Chemistry. 3 (2013) 20.

[10] G.D. Vuković, A.D. Marinković, M. Čolić, M.Đ. Ristić, R. Aleksić, A.A. Perić-Grujić, et al., Removal of cadmium from aqueous solutions by oxidized and ethylenediaminefunctionalized multi-walled carbon nanotubes, Chemical Engineering Journal. 157 (2010) 238-248.

[11] X. Ren, C. Chen, M. Nagatsu, X. Wang, Carbon nanotubes as adsorbents in environmental pollution management: A review, Chemical Engineering Journal. 170 (2011) 395-410.

[12] A.H. El-Sheikh, Y.S. Al-Degs, R.M. Al-As'ad, J. a. Sweileh, Effect of oxidation and geometrical dimensions of carbon nanotubes on $\mathrm{Hg}(\mathrm{II})$ sorption and preconcentration from real waters, Desalination. 270 (2011) 214-220.

[13] Y. Tao, Z. Lin, X.-M. Chen, X. Huang, M. Oyama, X. Wang, Functionalized multiwall carbon nanotubes combined with bis(2,2'-bipyridine)-5-amino-1,10-phenanthroline ruthenium(II) as an electrochemiluminescence sensor, Sensors and Actuators B: Chemical. 129 (2008) 758-763.

[14] G.D. Vuković, A.D. Marinković, S.D. Škapin, M.Đ. Ristić, R. Aleksić, A. a. Perić-Grujić, et al., Removal of lead from water by amino modified multi-walled carbon nanotubes, Chemical Engineering Journal. 173 (2011) 855-865.

[15] J.K. Lim, W.S. Yun, M. Yoon, S.K. Lee, C.H. Kim, K. Kim, et al., Selective thiolation of single-walled carbon nanotubes, Synthetic Metals. 139 (2003) 521-527.

[16] Y. Kim, T. Mitani, Surface thiolation of carbon nanotubes as supports: A promising route for the high dispersion of Pt nanoparticles for electrocatalysts, Journal of Catalysis. 238 (2006) 394-401.

[17] N.O. V Plank, R. Cheung, Thiolation of single-wall carbon nanotubes and their selfassembly, APPLIED PHYSICS LETTERS. 85 (2004) 3229-3231.

[18] C. Zhang, J. Sui, J. Li, Y. Tang, W. Cai, Efficient removal of heavy metal ions by thiolfunctionalized superparamagnetic carbon nanotubes, Chemical Engineering Journal. 210 (2012) 45-52. 
[19] D.A. Simoni, C. Airoldi, E.F.S. Vieira, I. De Quimica, U.E. De Campinas, C. Postal, Interaction of cations with SH-modified silica gel : thermochemical study through calorimetric titration and direct extent of reaction determination, 7 (1997) 2249-2252.

[20] B. Scheibe, E. Borowiak-palen, R.J. Kalenczuk, Oxidation and reduction of multiwalled carbon nanotubes - preparation and characterization, Materials Characterization. 61 (2010) 185-191.

[21] Z. Zang, Z. Hu, Z. Li, Q. He, X. Chang, Synthesis, characterization and application of ethylenediamine-modified multiwalled carbon nanotubes for selective solid-phase extraction and preconcentration of metal ions, 172 (2009) 958-963.

[22] A. Shahbazi, H. Younesi, A. Badiei, Functionalized SBA-15 mesoporous silica by melamine-based dendrimer amines for adsorptive characteristics of $\mathrm{Pb}(\mathrm{II}), \mathrm{Cu}(\mathrm{II})$ and $\mathrm{Cd}(\mathrm{II})$ heavy metal ions in batch and fixed bed column, Chemical Engineering Journal. 168 (2011) 505-518.

[23] H. Khan, M.J. Ahmed, M.I. Bhanger, A simple spectrophotometric determination of trace level mercury using 1,5-diphenylthiocarbazone solubilized in micelle., Analytical Sciences : the International Journal of the Japan Society for Analytical Chemistry. 21 (2005) 507-12.

[24] Y. Sağ, Y. Aktay, Application of equilibrium and mass transfer models to dynamic removal of $\mathrm{Cr}(\mathrm{VI})$ ions by Chitin in packed column reactor, Process Biochemistry. 36 (2001) 1187-1197.

[25] A. Heidari, H. Younesi, Z. Mehraban, Removal of $\mathrm{Ni}$ (II), $\mathrm{Cd}$ (II), and $\mathrm{Pb}$ (II) from a ternary aqueous solution by amino functionalized mesoporous and nano mesoporous silica, Chemical Engineering Journal. 153 (2009) 70-79.

[26] H. Qiu, L. Lv, B. Pan, Q. Zhang, W. Zhang, Q. Zhang, Critical review in adsorption kinetic models, Journal of Zhejiang University SCIENCE A. 10 (2009) 716-724.

[27] O. Moradi, K. Zare, Adsorption of $\mathrm{Pb}$ (II), $\mathrm{Cd}$ (II) and $\mathrm{Cu}$ (II) Ions in Aqueous Solution on SWCNTs and SWCNT - COOH Surfaces: Kinetics Studies, Fullerenes, Nanotubes and Carbon Nanostructures. 19 (2011) 628-652.

[28] D. Robati, Pseudo-second-order kinetic equations for modeling adsorption systems for removal of lead ions using multi-walled carbon nanotube, Journal of Nanostructure in Chemistry. 3 (2013) 55.

[29] A. a Farghali, M. Bahgat, W.M. a ElRouby, M.H. Khedr, Decoration of multi-walled carbon nanotubes (MWCNTs) with different ferrite nanoparticles and its use as an adsorbent, Journal of Nanostructure in Chemistry. 3 (2013) 50. 
[30] G. Yan, T. Viraraghavan, Heavy metal removal in a biosorption column by immobilized M. rouxii biomass., Bioresource Technology. 78 (2001) 243-9.

[31] D. Pokhrel, T. Viraraghavan, Arsenic removal in an iron oxide-coated fungal biomass column: analysis of breakthrough curves., Bioresource Technology. 99 (2008) 2067-71.

[32] A. Shahbazi, H. Younesi, A. Badiei, Batch and fixed-bed column adsorption of $\mathrm{Cu}(\mathrm{II})$, $\mathrm{Pb}(\mathrm{II})$ and $\mathrm{Cd}(\mathrm{II})$ from aqueous solution onto functionalised SBA-15 mesoporous silica, The Canadian Journal of Chemical Engineering. 91 (2013) 739-750.

[33] G. Vuković, A. Marinković, M. Obradović, V. Radmilović, M. Čolić, R. Aleksić, et al., Synthesis, characterization and cytotoxicity of surface amino-functionalized waterdispersible multi-walled carbon nanotubes, Applied Surface Science. 255 (2009) 80678075 .

[34] A. Jos, S. Pichardo, M. Puerto, E. Sánchez, A. Grilo, A.M. Cameán, Toxicology in Vitro Cytotoxicity of carboxylic acid functionalized single wall carbon nanotubes on the human intestinal cell line Caco-2, Toxicology in Vitro. 23 (2009) 1491-1496.

[35] K.K. Bansal, D. Kakde, U. Gupta, N.K. Jain, Development and characterization of triazine based dendrimers for delivery of antitumor agent, Journal of Nanoscience and Nanotechnology. 10 (2010) 8395-8404.

[36] K. Mori, Y. Sasaki, S. Sai, S. Kaneda, H. Hirahara, Y. Oishi, et al., Electrochemical polymerization of 2-(dioctylamino)-1, 3, 5-triazine-4, 6-dithiol on iron plates, Langmuir. 11 (1995) 1431-1434.

[37] J. Zhu, B. Deng, J. Yang, D. Gang, Modifying activated carbon with hybrid ligands for enhancing aqueous mercury removal, Carbon. 47 (2009) 2014-2025.

[38] L. Minati, G. Speranza, S. Torrengo, L. Toniutti, C. Migliaresi, D. Maniglio, et al., Characterization of thiol-functionalized carbon nanotubes on gold surfaces, Surface Science. 604 (2010) 1414-1419.

[39] F. Wang, Y. Wang, Y. Li, Preparation of 6-Diallylamino-1, 3, 5-Triazine-2, 4-Dithiol Functional Nanofilm by Electrochemical Polymerization Technique on Aluminum Surface, Int. J. Electrochem. Sci. 6 (2011) 793-803.

[40] B.A. Kakade, V.K. Pillai, An efficient route towards the covalent functionalization of single walled carbon nanotubes, Applied Surface Science. 254 (2008) 4936-4943.

[41] Y.Y.-S. Kim, J.J.-H. Cho, S.G. Ansari, H.-I.H. Kim, M.A. Dar, H.-K. Seo, et al., Immobilization of avidin on the functionalized carbon nanotubes, Synthetic Metals. 156 (2006) 938-943. 
[42] Y. Wang, Z. Iqbal, S. V Malhotra, Functionalization of carbon nanotubes with amines and enzymes, Chemical Physics Letters. 402 (2005) 96-101.

[43] M.C. Dujardin, C. Caze, I. Vroman, Ion-exchange resins bearing thiol groups to remove mercury.: Part 1: synthesis and use of polymers prepared from thioester supported resin, Reactive and Functional Polymers. 43 (2000) 123-132.

[44] L. Blue, P. Jana, D. Atwood, Aqueous mercury precipitation with the synthetic dithiolate, BDTH 2, Fuel. 89 (2010) 1326-1330.

[45] A. Hutchison, D. Atwood, Q.E. Santilliann-jiminez, The removal of mercury from water by open chain ligands containing multiple sulfurs, Journal of Hazardous Materials. 156 (2008) 458-465.

[46] K. Pillay, E.M. Cukrowska, N.J. Coville, Improved uptake of mercury by sulphurcontaining carbon nanotubes, Microchemical Journal. 108 (2013) 124-130.

[47] M. Sánchez-Polo, J. Rivera-Utrilla, Adsorbent-adsorbate interactions in the adsorption of $\mathrm{Cd}(\mathrm{II})$ and $\mathrm{Hg}$ (II) on ozonized activated carbons., Environmental Science \& Technology. 36 (2002) 3850-4.

[48] Y.-S.L. Cheng-Chung Liu, Ming Kuang-Wang, Removal of Nickel from Aqueous Solution Using Wine Processing Waste Sludge, Industrial \& Engineering Chemistry Research. 44 (2005) 1438-1445.

[49] Y. Liu, Y.-J. Liu, Biosorption isotherms, kinetics and thermodynamics, Separation and Purification Technology. 61 (2008) 229-242.

[50] G. Rao, C. Lu, F. Su, Sorption of divalent metal ions from aqueous solution by carbon nanotubes: A review, Separation and Purification Technology. 58 (2007) 224-231. 


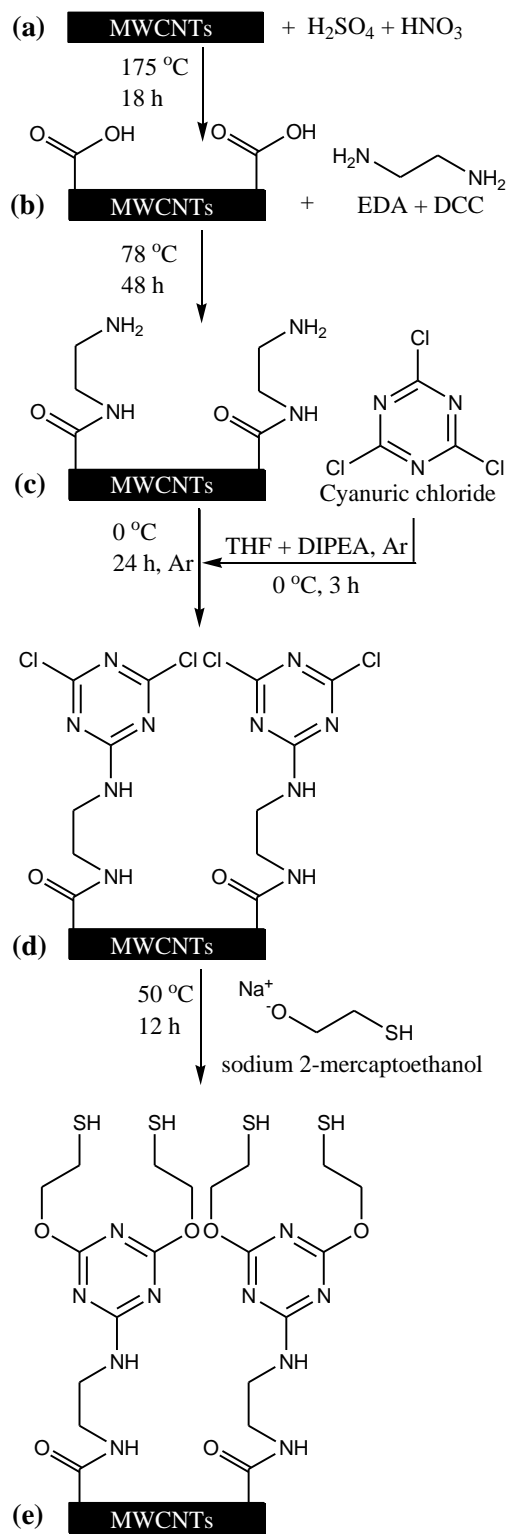

Fig. 1. Schematic of the functionalization of the MWCNTs.

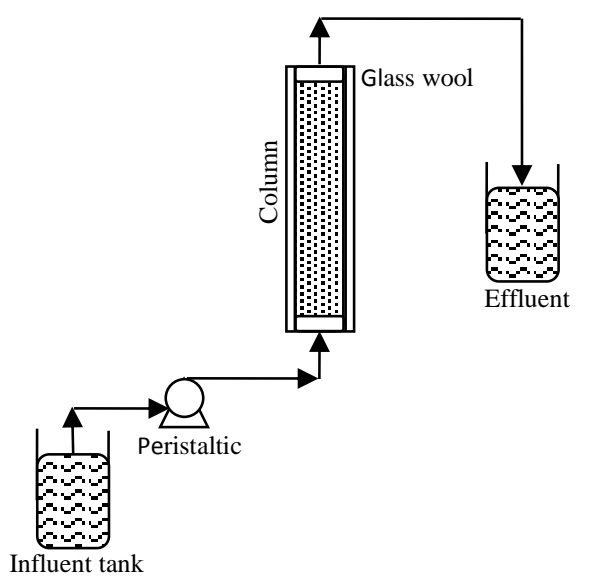


Fig. 2. Schematic diagram for the fixed-bed glass column.

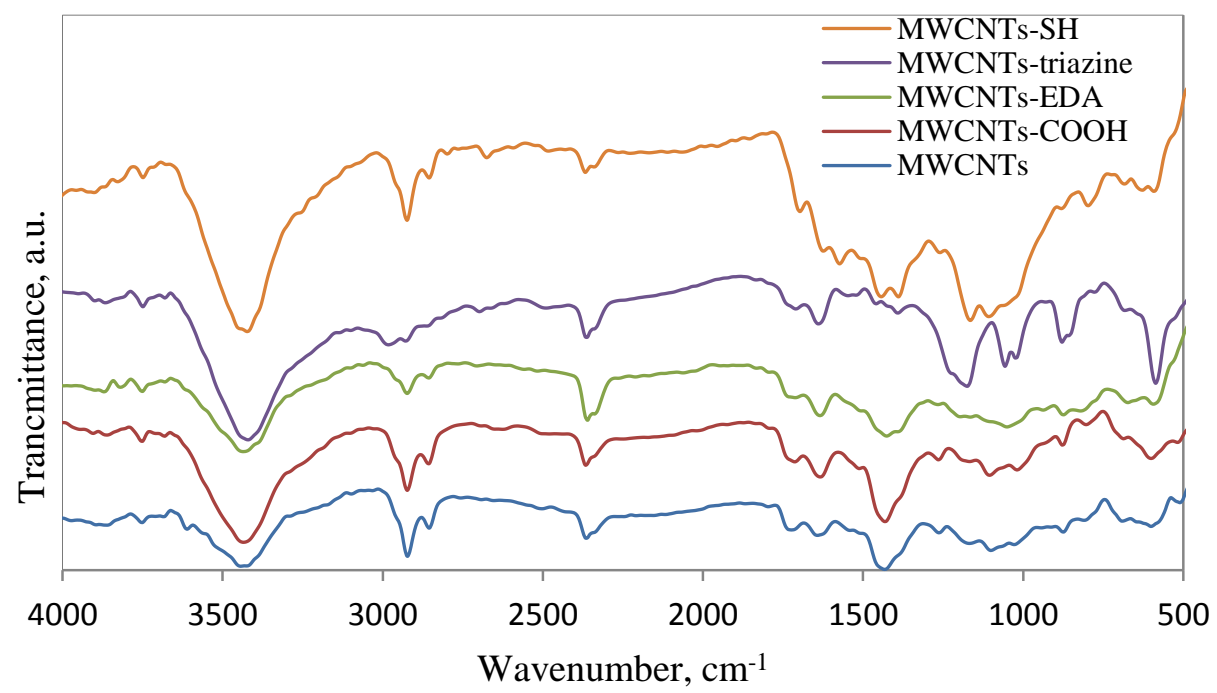

(a)

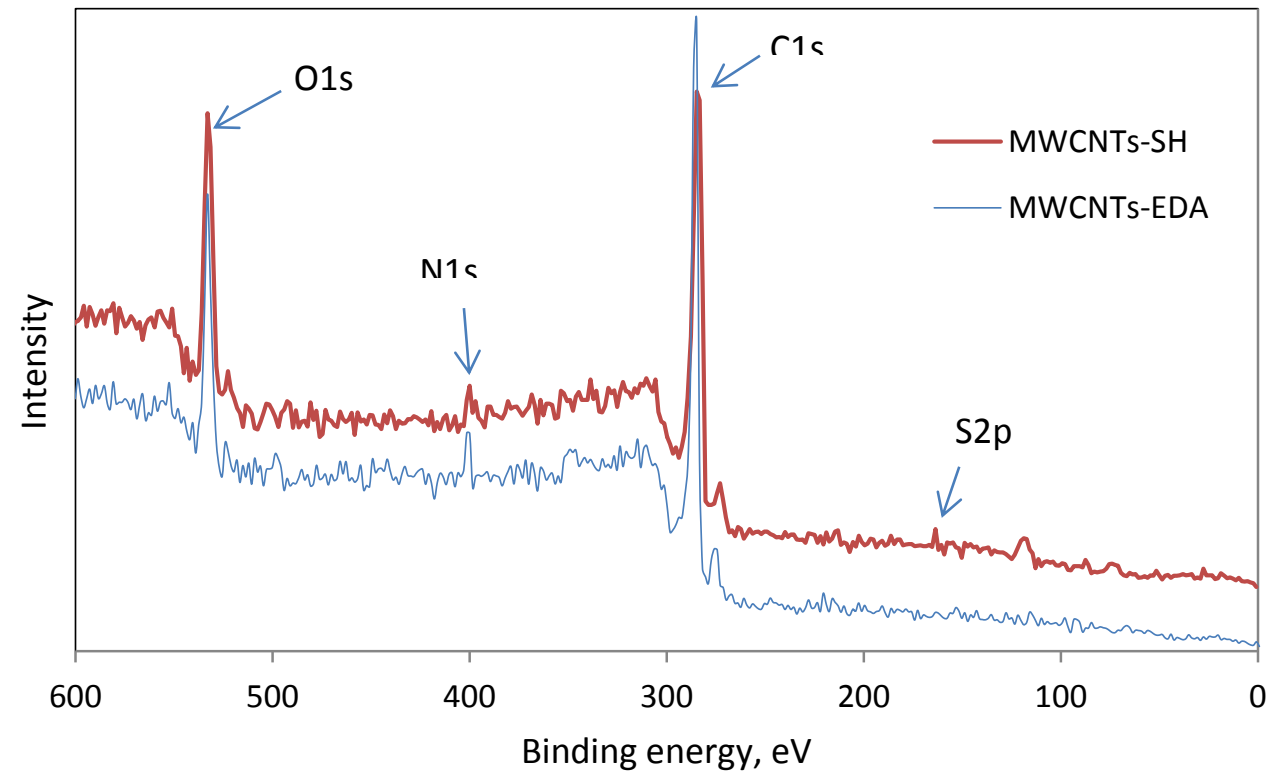

(b) 


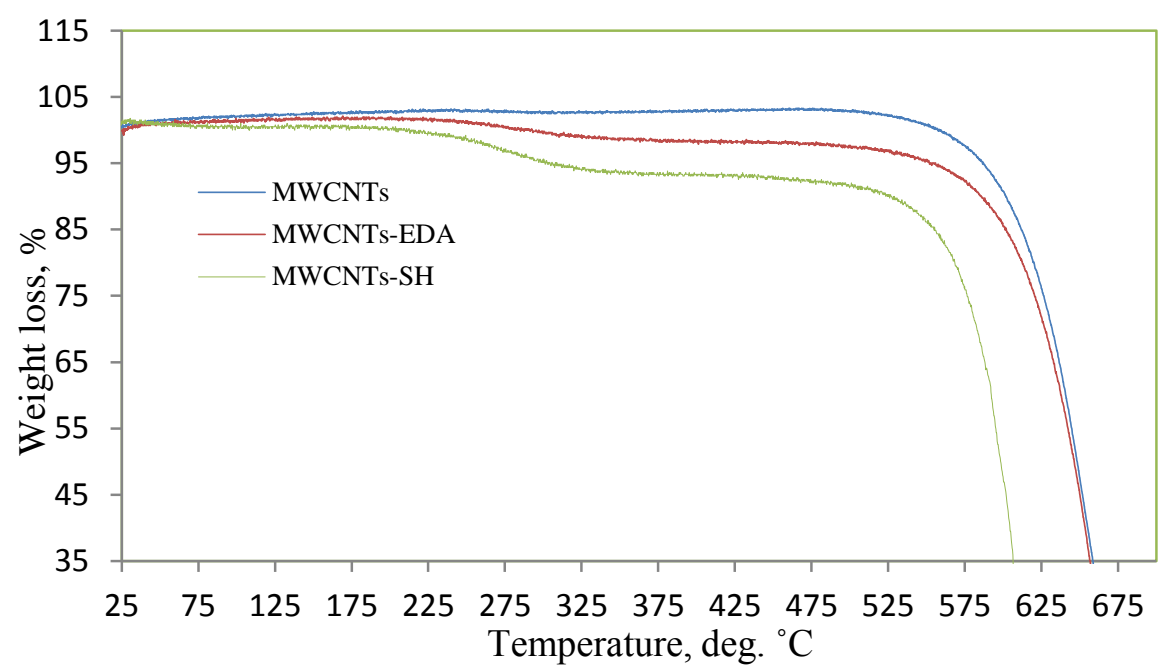

(c)

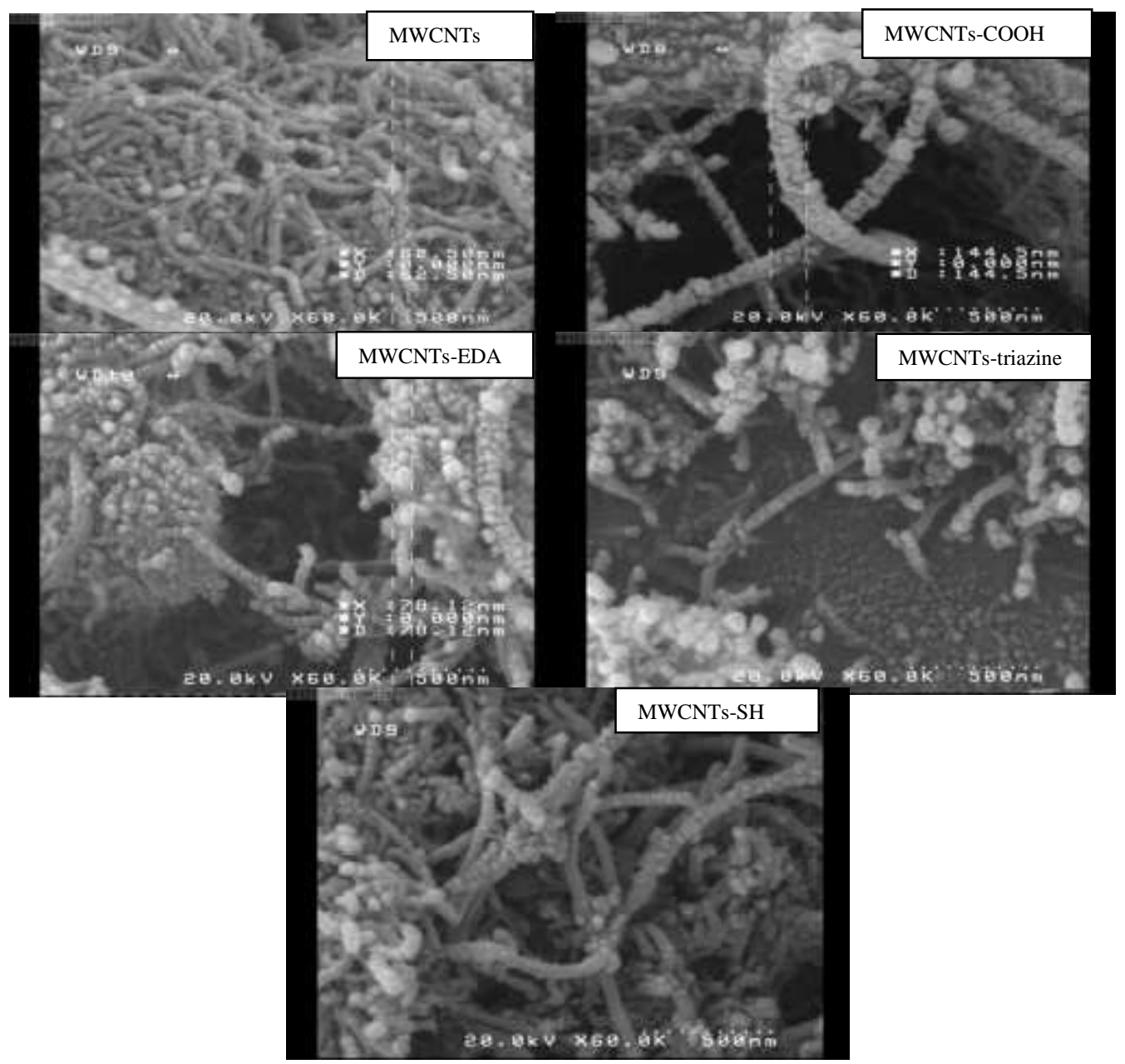

(d)

Fig. 3. Characteristics of functionalized MWCNTs (a) FT-IR spectra of pristine and functionalized MWCMTs, (b) XPS spectra of wide scan of the MWCNTs-EDA and MWCNTs$\mathrm{SH}$, (c) TGA curves and (d) scanning electron microscope. 


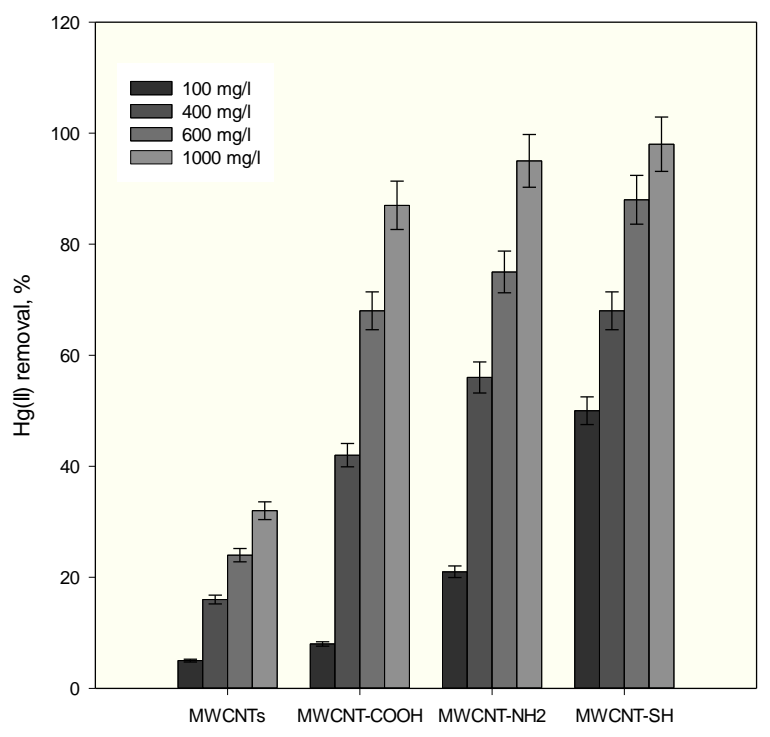

Fig. 4. Effect of adsorbent dose on the $\mathrm{Hg}(\mathrm{II})$ removal by pristine and functionalized MWCNTs. Conditions: initial $\mathrm{Hg}$ (II) concentration $10 \mathrm{mg} / \mathrm{l}$, initial $\mathrm{pH}$ value 7, agitation time $60 \mathrm{~min}$ at 200 rpm and $25^{\circ} \mathrm{C}$.

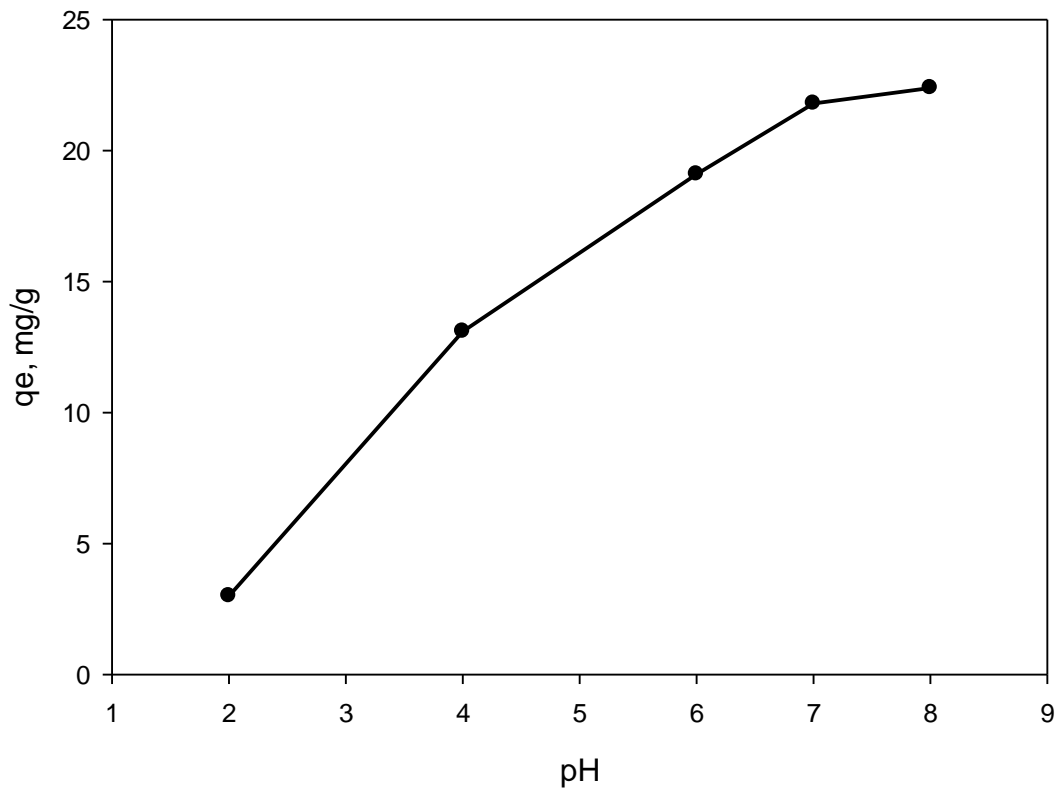

Fig 5. Effect of $\mathrm{pH}$ on $\mathrm{Hg}(\mathrm{II})$ removal. Conditions: adsorbent dose $400 \mathrm{mg} / \mathrm{l}$, initial concentration $10 \mathrm{mg} / \mathrm{l}$, agitation time $60 \mathrm{~min}$ in $200 \mathrm{rpm}$ and at $25^{\circ} \mathrm{C}$. 


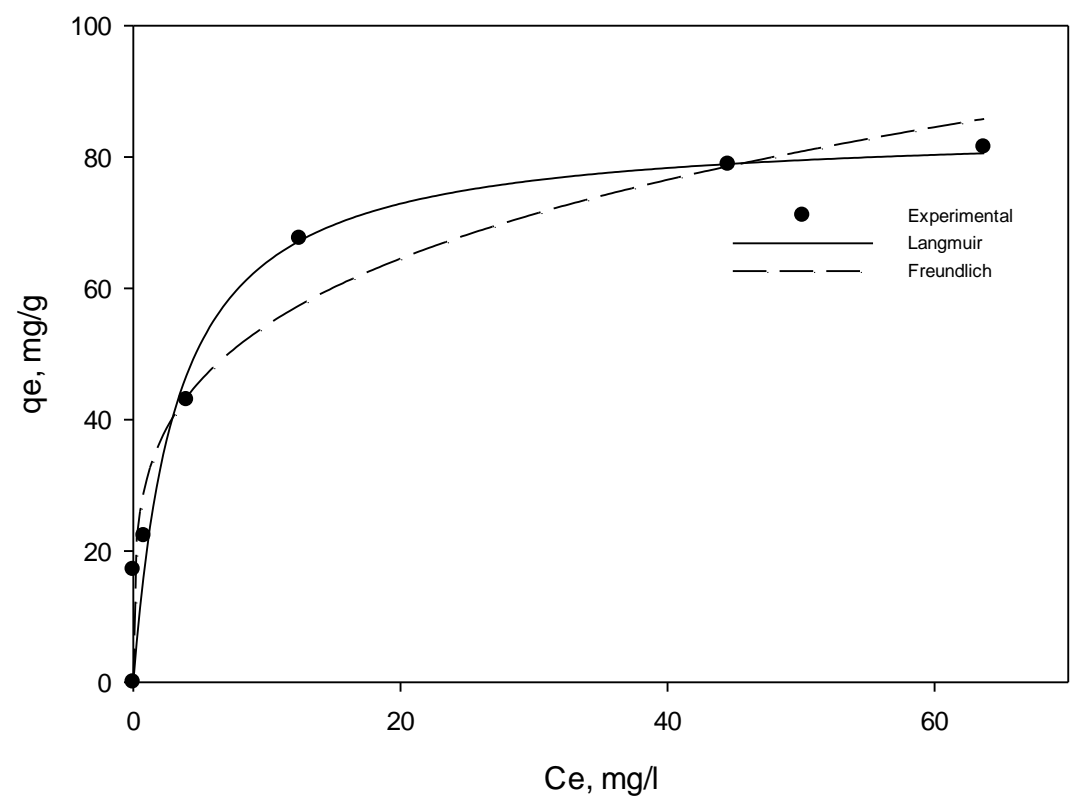

Fig. 6. Adsorption isotherm of $\mathrm{Hg}$ (II) on MWCNT-SH at initial metal ions concentration from 5-100 mg/l, adsorbent dose of $400 \mathrm{mg} / \mathrm{l}, \mathrm{pH} 6.0$ and temperature of $25^{\circ} \mathrm{C}$ for $60 \mathrm{~min}$.

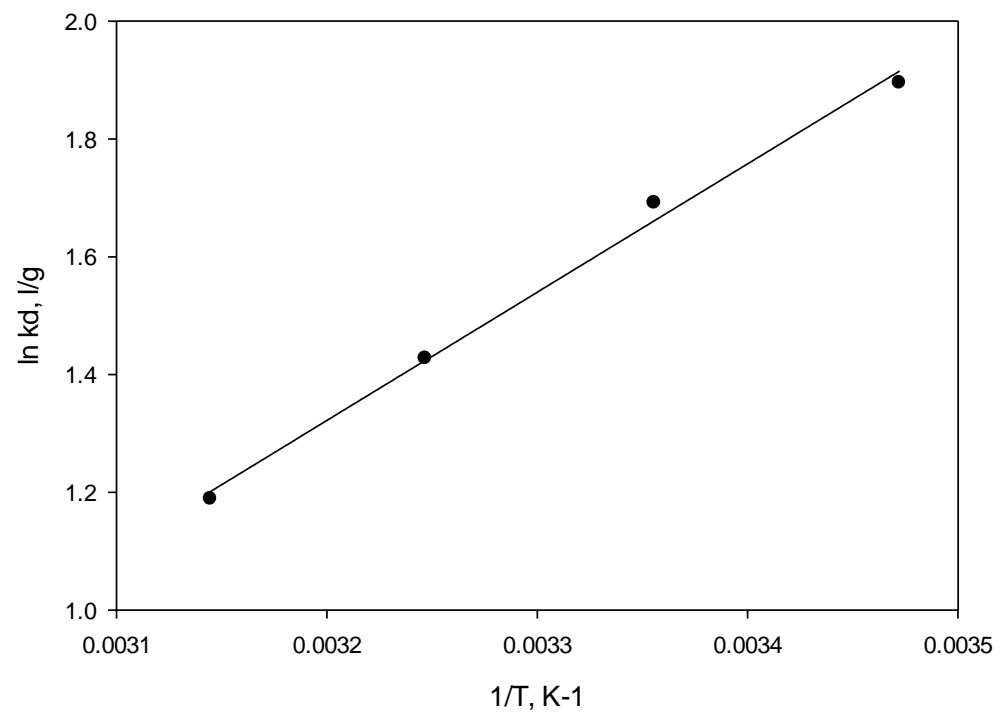

Fig. 7. Plots of $\ln k_{\mathrm{d}}$ versus $1 / T$ for $\mathrm{Hg}(\mathrm{II})$ adsorption on MWCNT-SH at the adsorbent dose of $400 \mathrm{mg} / \mathrm{l}, \mathrm{pH} 6.0$ and different temperatures. 


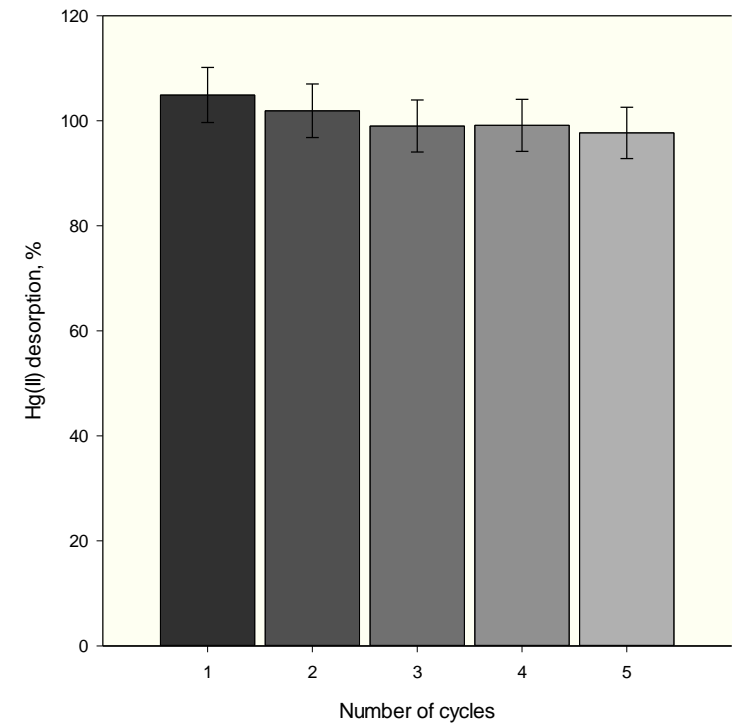

Fig. 8. The number of adsorption-desorption cycle of $\mathrm{Hg}(\mathrm{II})$ on MWCNT-SH.

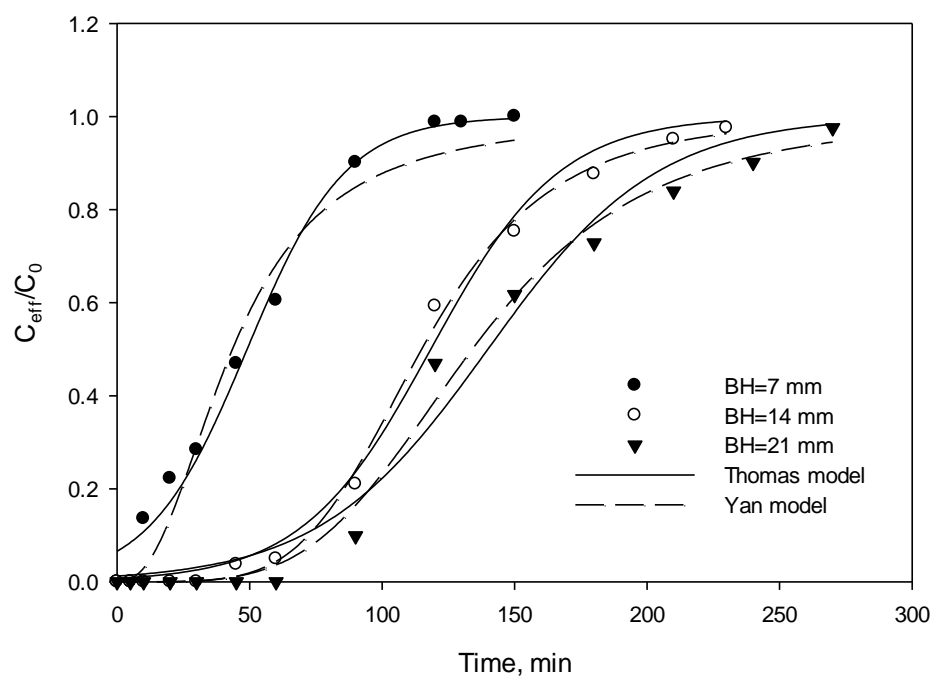

(a) 


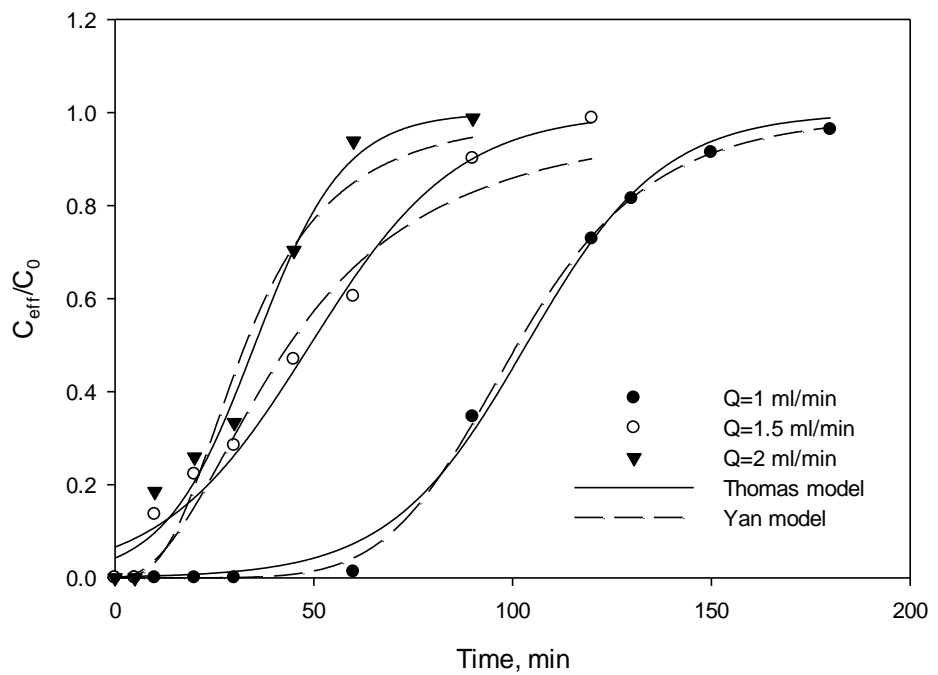

(b)

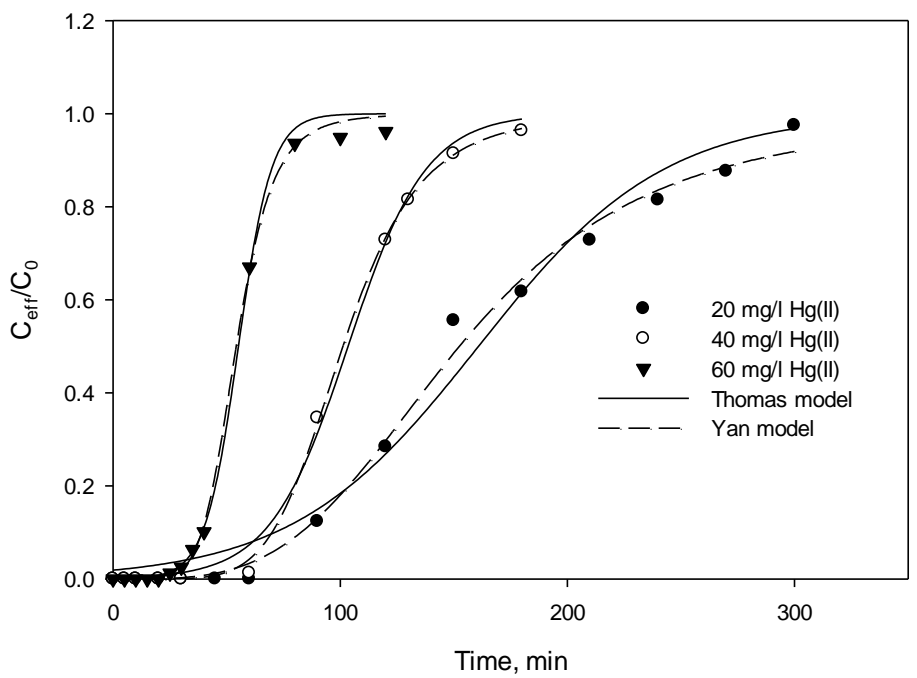

(c)

Fig. 9. Experimental (symbols) and theoretical (solid and dotted lines) breakthrough curves in (a) different bed heights, (b) different flow rates and (c) different influent ion concentration for $\mathrm{Hg}$ (II) removal by the MWCNT-SH. 


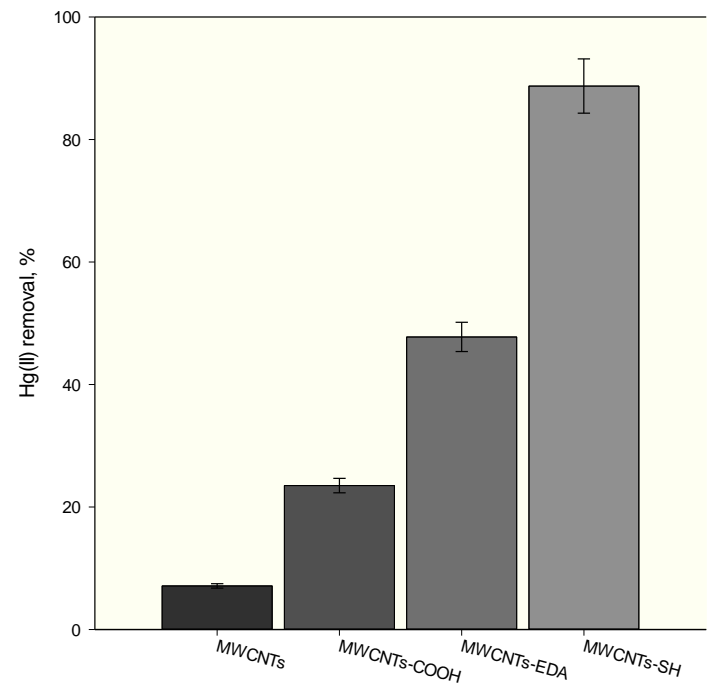

Fig. 10. Removal of $\mathrm{Hg}$ ions from chloralkali wastewater with different adsorbents. Adsorbent dose $200 \mathrm{mg} / \mathrm{l}, \mathrm{pH}=6$ and room temperature. 
Table 1. Langmuir and Freundlich parameters for adsorption of $\mathrm{Hg}(\mathrm{II})$ onto MWCNT-SH

\begin{tabular}{llllll}
\hline Langmuir & \multicolumn{5}{c}{ Freundlich } \\
\hline$q_{m}(\mathrm{mg} / \mathrm{g})$ & $b(\mathrm{l} / \mathrm{mg})$ & $R^{2}$ & $n$ & $k_{f}$ & $R^{2}$ \\
\hline 84.66 & 0.31 & 0.945 & 0.301 & 30.924 & 0.926 \\
\hline
\end{tabular}

Table 2. Thermodynamic parameters of $\mathrm{Hg}$ (II) adsorption on MWCNT-SH at different temperatures in Kelvin (initial concentration of metal ion $40 \mathrm{mg} / \mathrm{l}$ ).

\begin{tabular}{|c|c|c|c|c|c|c|}
\hline$\Delta \mathrm{H}^{\circ}\left(\mathrm{kJ} \mathrm{mol}^{-1}\right)$ & $\Delta \mathrm{S}^{\circ}\left(\mathrm{kJ}^{-1} \mathrm{~mol}^{-1} \mathrm{~K}^{-1}\right)$ & $\Delta \mathrm{G}^{\circ}(\mathrm{k}$ & & & & $\mathrm{R}^{2}$ \\
\hline & & $288 \mathrm{~K}$ & $298 \mathrm{~K}$ & $308 \mathrm{~K}$ & $318 \mathrm{~K}$ & \\
\hline-18.12 & -0.047 & -4.59 & -4.12 & -3.65 & -3.18 & 0.995 \\
\hline
\end{tabular}

Table 3. Kinetic adsorption parameters obtained using pseudo-first-order and pseudo-second-order models

\begin{tabular}{llllllll}
\hline Metal conc. $(\mathrm{mg} / \mathrm{l})$ & $q_{\mathrm{e}}{ }^{\mathrm{exp}}(\mathrm{mg} / \mathrm{g})$ & \multicolumn{4}{l}{ Pseudo-first-order } & \multicolumn{4}{l}{ Pseudo-second-order } \\
\hline 5 & & $k_{1}\left(\mathrm{~min}^{-1}\right)$ & $q_{\mathrm{e} 1}(\mathrm{mg} / \mathrm{g})$ & $R^{2}$ & $k_{2}(\mathrm{~g} / \mathrm{mg} \mathrm{min})$ & $q_{\mathrm{e} 2}(\mathrm{mg} / \mathrm{g})$ & $\mathrm{R}^{2}$ \\
\hline 10 & 16.85 & 0.41 & 10.91 & 0.8720 & 2.05 & 16.94 & 1.0000 \\
\hline 20 & 22.65 & 0.028 & 6.02 & 0.7680 & 0.02 & 22.73 & 0.9990 \\
\hline 40 & 41.66 & 0.07 & 14.48 & 0.5820 & 0.027 & 41.66 & 0.9980 \\
\hline 80 & 70.00 & 0.023 & 26.67 & 0.7810 & 0.0038 & 70.92 & 0.9990 \\
\hline 100 & 82.07 & 0.018 & 24.1 & 0.5490 & 0.0042 & 81.97 & 0.9990 \\
\hline
\end{tabular}


Table 4. The breakthrough parameters and predicted values of Thomas and Yan models for $\mathrm{Hg}$ (II) removal at various column conditions.

\begin{tabular}{llllllllllllll}
\hline \multicolumn{2}{l}{ Column condition } & \multicolumn{3}{l}{ Breakthrough analysis $^{\mathrm{b}}$} & \multicolumn{3}{c}{ Thomas model $^{\mathrm{c}}$} & \multicolumn{3}{c}{ Yan $_{\text {model }}^{\mathrm{d}}$} \\
\hline $\mathrm{BH}$ & $\mathrm{Q}$ & Conc. & $q_{\mathrm{e}}$ & $R, \%$ & $\mathrm{C}_{\mathrm{e}}$ & $\mathrm{MTZ}$ & $\mathrm{q}_{\mathrm{Th}}$ & $\mathrm{k}_{\mathrm{Th}} \times 10^{4}$ & $\mathrm{R}^{2}$ & $\mathrm{q}$ & $\mathrm{a}$ & $\mathrm{R}^{2}$ \\
\hline 7 & 1 & 40 & 105.65 & 64.03 & 14.38 & 4.41 & 103.4 & 14.57 & 0.996 & 101.13 & 5.950 & 0.999 \\
\hline 7 & 1.5 & 40 & 76.42 & 42.46 & 23.01 & 6.35 & 73.52 & 13.5 & 0.995 & 65.23 & 2.371 & 0.975 \\
\hline 7 & 2 & 40 & 71.47 & 52.55 & 18.97 & 6.79 & 70.18 & 22.18 & 0.978 & 65.38 & 2.854 & 0.957 \\
\hline 7 & 1 & 20 & 83.08 & 55.34 & 8.93 & 5.46 & 80.4 & 12.25 & 0.997 & 76.19 & 3.591 & 0.994 \\
\hline 7 & 1 & 60 & 86.28 & 69.30 & 18.61 & 4.13 & 82.71 & 22.88 & 0.982 & 81.223 & 6.644 & 0.999 \\
\hline 14 & 1.5 & 40 & 91.37 & 57.19 & 17.12 & 9.9 & 88.74 & 10.32 & 0.994 & 86.16 & 4.717 & 0.998 \\
\hline 21 & 1.5 & 40 & 72.86 & 53.97 & 18.41 & 16.02 & 69.94 & 7.83 & 0.980 & 66.98 & 4.074 & 0.993 \\
\hline
\end{tabular}

${ }^{\mathrm{a}} \mathrm{BH}$ : bed height (mm); Q: flow rate ( $\left.\mathrm{ml} / \mathrm{min}\right)$; Conc.: influent metal ion concentration $(\mathrm{mg} / \mathrm{l})$.

${ }^{\mathrm{b}} \mathrm{q}_{\mathrm{e}}$ : adsorption capacity (mg/g); R\%: removal percentage; $\mathrm{C}_{\mathrm{e}}$ : equilibrium concentration (mg/l); MTZ: mass transfer zone (mm).

${ }^{\mathrm{c}} \mathrm{k}_{\mathrm{Th}}$ : Thomas rate constant (ml/min/mg); $\mathrm{q}_{\mathrm{Th}}$ : Thomas maximum adsorption capacity (mg/g).

${ }^{\mathrm{d}}$ a: Yan rate constant (dimensionless); $\mathrm{q}_{\mathrm{Y}}$ : Yan maximum adsorption capacity $(\mathrm{mg} / \mathrm{g})$.

Table 5. Characteristics of chloralkali wastewater

\begin{tabular}{ll}
\hline Characteristics & Values \\
\hline $\mathrm{pH}$ & 6 \\
$\mathrm{TS}$ & $24 \mathrm{~g} / \mathrm{l}$ \\
$\mathrm{TVS}$ & $325 \mathrm{mg} / \mathrm{l}$ \\
$\mathrm{EC}$ & $43.5 \mathrm{mS} / \mathrm{cm}$ \\
$\mathrm{Cl}^{-}$ & $12800 \mathrm{mg} / \mathrm{l}$ \\
$\mathrm{Na}^{+}$ & $9300 \mathrm{mg} / \mathrm{l}$ \\
$\mathrm{K}^{+}$ & $38 \mathrm{mg} / \mathrm{l}$ \\
$\mathrm{Mg}^{+2}$ & $40 \mathrm{mg} / \mathrm{l}$ \\
$\mathrm{Zn}^{+2}$ & $10 \mathrm{mg} / \mathrm{l}$ \\
$\mathrm{Fe}^{+2}$ & $1.2 \mathrm{mg} / \mathrm{l}$ \\
$\mathrm{Mn}^{+2}$ & $0.03 \mathrm{mg} / \mathrm{l}$ \\
$\mathrm{Hg}$ & $64.7 \mu \mathrm{g} / \mathrm{l}$ \\
\hline
\end{tabular}

